\title{
Hydrological dynamics and fire history of the last 1300 years in western Siberia reconstructed from a high-resolution, ombrotrophic peat archive
}

\author{
Mariusz Lamentowicz ${ }^{\mathrm{a}, \mathrm{b}}$, Michał Słowiński ${ }^{\mathrm{c}, \mathrm{d}}$, Katarzyna Marcisz ${ }^{\mathrm{a}, \mathrm{b}}$, Małgorzata \\ Zielińska $^{\mathrm{a}, \mathrm{b}}$, Karolina Kaliszan ${ }^{\mathrm{a}}$, Elena Lapshina ${ }^{\mathrm{e}}$, Daniel Gilbert ${ }^{\mathrm{f}}$, Alexandre Buttler ${ }^{\mathrm{f}}$, , h, \\ Barbara Fiałkiewicz-Kozieł ${ }^{\mathrm{b}}$, Vincent E.J. Jassey ${ }^{\mathrm{g}}$, , Fatima Laggoun-Defarge ${ }^{\mathrm{i}}$, Piotr \\ Kołaczek $^{\mathrm{b}}$
}

- ${ }^{a}$ Laboratory of Wetland Ecology and Monitoring, Faculty of Geographical and Geological Sciences, Adam Mickiewicz University, Dzięgielowa 27, PL-61 680 Poznań, Poland

- ${ }^{\mathrm{b}}$ Department of Biogeography and Paleoecology, Adam Mickiewicz University, Dzięgielowa 27, 61-680 Poznań, Poland

- ${ }^{\mathrm{c}}$ Department of Environmental Resources and Geohazards, Institute of Geography and Spatial Organization, Polish Academy of Sciences, Kopernika 19, 87-100 Torun, Poland

- ${ }^{\mathrm{d}}$ GFZ German Research Centre for Geosciences, Section 5.2-Climate Dynamics and Landscape Evolution, Telegrafenberg, D-14473 Potsdam, Germany

- ${ }^{\mathrm{e}}$ Yugra State University, Chekhova 16, 628012 Khanty-Mansiysk, Russia

- $\quad{ }^{\mathrm{f}}$ Laboratoire de Chrono-environment, UMR 6249 CNRS, Université de FrancheComté, 16 Route de Gray, 25030 Besancon Cedex, France

- ${ }^{\mathrm{g}}$ Swiss Federal Research Institute-WSL, Community Ecology Research Unit, Station 2, CH-1015 Lausanne, Switzerland

- ${ }^{\mathrm{h}}$ ÉcolePolytechniqueFédérale de Lausanne (EPFL), School of Architecture, Civil and Environmental, Engineering (ENAC), Laboratory of Ecological Systems (ECOS), Station 2, CH-1015 Lausanne, Switzerland

- $\quad{ }^{\text {i } U n i v e r s i t e ́ d ' O r l e ́ a n s, ~ C N R S / I N S U, ~ B R G M, ~ I S T O, ~ U M R, ~} 45071$ Orléans, France

\begin{abstract}
Siberian peatlands provide records of past changes in the continental climate of Eurasia. We analyzed a core from Mukhrino mire in western Siberia to reconstruct environmental change in this region over the last 1300 years. The pollen analysis revealed little variation of local pine-birch forests. A testate amoebae transfer function was used to generate a quantitative water-table reconstruction; pollen, plant macrofossils, and charcoal were analyzed to reconstruct changes in vegetation and fire activity. The study revealed that Mukhrino mire was wet until the Little Ice Age (LIA), when drought was recorded. Dry conditions during the LIA are consistent with other studies from central and eastern Europe, and with the pattern of carbon accumulation across the Northern Hemisphere. A significant increase in fire activity between ca. AD 1975 and 1990 may be associated with the development of the nearby city of Khanty-Mansiysk, as well as with the prevailing positive Arctic Oscillation.
\end{abstract}

\section{Keywords}

- Testate amoebae; Pollen; Macrofossils; Transfer function; Peat; Siberia; Charcoal

This document is the accepted manuscript version of the following article: Lamentowicz, M., Słowiński, M., Marcisz, K., Zielinska, M., Kaliszan, K., Lapshina, E., ... Kołaczek, P. (2015). Hydrological dynamics and fire history of the last 1300 years in western siberia reconstructed from a high-resolution, ombrotrophic peat archive. Quaternary Research, 84(3), 312-325. https://doi.org/10.1016/j.yqres.2015.09.002 


\section{Introduction}

Northern hemisphere peatlands are important archives of past environmental change and sinks of carbon (Charman, 2002; Loisel et al., 2014). However, climate change and human impacts (e.g. wetland drainage and nutrient deposition) trigger increased emission of this stored carbon into the atmosphere (Payne et al., 2013; Ward et al., 2013). Given these ongoing stressors, there is an urgent need to better understand the various processes involved in peatland dynamics (Dise, 2010; Loisel and Yu, 2013). Paleoenvironmental approaches provide a useful perspective on the present state and long-term history of peatlands (Seddon et al., 2014), and the application of coupled biotic and abiotic proxies enables a detailed reconstruction of climate change, peatland ecosystem development, and changes in the surrounding landscape (Gałka et al., 2013).

The last millennium is a critical period for paleoenvironmental study, as it features both climatic variability, such as the Medieval Warm Period (MWP) and the Little Ice Age (LIA), and increasing anthropogenic impacts, leading up to the dramatic increases in pollution and global temperatures observed over the last 200 years(Jones and Mann, 2004).Peatland ecosystems experience various types of anthropogenic and natural disturbances, including wetland drainage, forest management, and fire (Dise, 2010). The response of peatlands to disturbance and climate change has been well studied in Europe (Lamentowicz et al., 2008; Lamentowicz et al., 2011; van der Knaap et al., 2011),but the paleoecology of Siberian bogs remains largely unexplored.

The hydrological dynamics of Siberian peatlands over the last millennium are of particular interest, and testate amoebae, protists that are abundant in peatlands and sensitive to hydrological conditions, can be used as a reliable proxy for the quantitative reconstruction of past variability in water tables (Blundell et al., 2008; Booth et al., 2008; Hendon and Charman, 2004; Turner et al., 2014). However, while some research has explored the ecology and taxonomy of testate amoebae in Siberian bogs (Bobrov et al., 2013; Kurina et al., 2010; Muller et al., 2009), modern calibration studies have not been carried out in this region. Such calibration data sets for testate amoebae are urgently needed so that this proxy can be utilized for the reconstruction of past hydrological variations in western Siberia. 
Several analyses of Siberian peatlands have focused on carbon accumulation (Beilman et al., 2009; Borren et al., 2004; Lapshina and Plogova, 2011; Lapshina et al., 2001; Turunen et al., 2001), but few peatland studies in this region have generated paleoecological inferences (Bobrov et al., 2013; Kremenetski et al., 2003; Liss et al., 2001; Peregon et al., 2007a; Peregon et al., 2007b; Pitkänen et al., 2002). This is in contrast to work in Northwest Europe and North America, where a large number of high-resolution, multi-proxy studies have been performed in peatlands (Blundell and Barber, 2005; Booth et al., 2006; Kaislahti Tillman et al., 2010; Swindles et al., 2007; Turner et al., 2014). The lack of such studies in Siberia is unfortunate, as Siberian peatlands cover much larger areas than in other parts of Eurasia. Moreover, paleoenvironmental records from Siberian peatlands have the potential to improve our understanding of past changes in both the continental climate of Eurasia and pristine vegetation that no longer exists in Europe (Solomeshch, 2005).

Charcoal records from peatlands have been used to reconstruct past fire activity in Europe (Gałka et al., 2013; Sillasoo et al., 2011) and North America (Lavoie and Pellerin, 2007), but only limited research of this type has been carried out in Siberia (Turunen et al., 2001),despite the global importance of peatland fires (Turetsky et al., 2015). It is believed that during the last decade burning has increased in Siberia due to the prevailing positive Arctic Oscillation (Balzter et al., 2005). This relationship can only be verified with a paleoecological approach, since mapped fire data and instrumental weather data cover only short time scales. Over longer intervals, increased fire activity may be related to the prolonged drought events that are recorded by hydrological changes in peatlands. Charcoal data have not been regularly compared to quantitative paleohydrological reconstructions (Tweiten et al., 2009). Nevertheless, the study by Marcisz et al. (2015) showed that a coupled analysis of charcoal and testate amoebae could improve our understanding of past droughts and heat waves overlong temporal scales.

In this study we apply three methodological approaches that previously have not been used together in Siberia: (i) a testate amoebae transfer function was used for a quantitative water table reconstruction; (ii) pollen and plant macrofossils were used to reconstruct vegetation history; and (iii) a charcoal record was used to infer past fire 
activity. The integration of these proxies allows us to explore the response of boreal peatlands, forest communities, and fire regimes to climate change. This research focus aligns well with the PAGES-Asia2k research program (Ahmed et al., 2013). A modern calibration study also improves our understanding of testate amoebae ecology in the boreal region of Siberia.

\section{Study site}

The Mukhrino mire is located on the eastern bank of the Irtysh River, near the confluence with the $\mathrm{Ob}$ River in the middle taiga area of western Siberia, about $20 \mathrm{~km}$ from Khanty-Mansiysk ( $\left.60^{\circ} 54^{\prime} \mathrm{N}, 68^{\circ} 42^{\prime} \mathrm{E}\right)$. This region is located in the Boreal climate zone, which corresponds to the Sub-Arctic climate zone of western Europe (Fig. 1). The mean annual temperature is $-1.3^{\circ} \mathrm{C}$, the coldest month being January, with a mean temperature of $-18.9^{\circ} \mathrm{C}$; the warmest month is July, with a mean temperature of $17.1^{\circ} \mathrm{C}$. The mean annual precipitation is $553 \mathrm{~mm}$ (Kremenetski et al., 2003). In 2009, the Mukhrino Field Station was built at the margin of a giant mire complex. It is managed by the UNESCO Chair of Environmental Dynamics and Climate Change at Yugra State University, Khanty-Mansiysk, Russia (Elger et al., 2012). The Mukhrino mire complex is typical for the West Siberian middle taiga. It is a complex of oligotrophic-raised bogs (Pinus sylvestris and P. sibirica, Eriophorum vaginatum, Ledum palustre, Chamaedaphne calyculata, Betula nana, and Sphagnum fuscum) patterned with ridge-hollows (Carex limosa, Scheuchzeria palustris, Sphagnum balticum, S. jensenii,and S. papillosum) and oligo-mesotrophic fens (Carex rostrata, Menyanthes trifoliata, E. russeolum, S. fallax, $S$. jensenii, and S. majus) (Filippov and Lapshina, 2008). This area is characterized by the absence of permafrost (Bleuten and Filippov, 2008). The Mukhrino peatland has a peat thickness between $3 \mathrm{~m}$ and $4.5 \mathrm{~m}$. Its hydrology is dependent on micro-topography and changes seasonally. During the summer, groundwater in poor fens and hollows is between $5 \mathrm{~cm}$ and $20 \mathrm{~cm}$ below the moss surface, while in raised bog areas with Sphagnum hummocks the water table is $40 \mathrm{~cm}$ to $80 \mathrm{~cm}$ below the surface (Bleuten and Filippov, 2008). 


\section{Materials and methods}

\section{Field sampling}

In summer 2012, a $1 \mathrm{~m}$ peat core was sampled with a long serrated knife and sliced in the field into $1 \mathrm{~cm}$ samples. Each slice was divided into four subsamples to be used in the four analyses. These peat samples were then packed into plastic bags and transported to the laboratory. They were kept refrigerated until processing.

In addition, 65 moss samples and 5 liverworts were collected in the summers of 2012 and 2013 in the mire around Mukhrino station for the construction of a calibration data set to be used in the testate amoebae transfer function. Surface samples were taken along a wet-dry gradient from pools to the tops of hummocks. Water table depth was measured once during the sampling campaign, together with $\mathrm{pH}$ and conductivity.

\section{Chronology and peat accumulation rate}

Eleven AMS (Accelerator Mass Spectroscopy) ${ }^{14} \mathrm{C}$ dates were obtained in the Poznań Radiocarbon Laboratory (Poland) in 2013. The samples subjected to dating contained Sphagnum stems and leaves and these were carefully cleaned from rootlets to avoid contamination by younger carbon (Table 1). The basis for the chronology of the Mukhrino peat profile is a Bayesian age-depth model constructed using the OxCal v. 4.2 program (Bronk Ramsey, 2008), with the application of the IntCal13 (Reimer et al., 2013) and NH1 post-bomb (Hua et al., 2013) atmospheric curves. For the calculation of the model with a $0.5 \mathrm{~cm}$ resolution, the $P_{-}$Sequence function with parameters $k_{0}=1$ and $\log _{10}\left(k / k_{0}\right)=0.3$ was applied. The most distinct changes in the peat structural composition and pollen concentration of the profile were introduced using the Boundary command. The first boundaries were established at depths of $100 \mathrm{~cm}$ and $0 \mathrm{~cm}$ (the bottom and top of the model, respectively), followed by $86.5 \mathrm{~cm}$ and $50.5 \mathrm{~cm}$ (both reflecting rapid changes in pollen concentration and bulk density (cf. Fiałkiewicz-Kozieł et al., 2015)). The age of the top of profile $(0 \mathrm{~cm})$ was setas AD 2012.7 (the August 2012 - the date of the core retrieval). Hereafter, ages are presented as median $(\mu)$ values of the modeled ages, and expressed as AD years. The peat accumulation rate (P), 
expressed as $\mathrm{cm} / \mathrm{yr}$, was calculated according to the formula: $P_{\text {depth }}=1 \mathrm{~cm} /\left(\mu_{\mathrm{depth}-0.5 \mathrm{~cm}-}\right.$

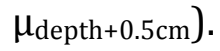

\section{Pollen and charcoal}

Twenty-four samples $\left(1 \mathrm{~cm}\right.$ thick, each $2 \mathrm{~cm}^{3}$ in volume) were prepared with a standard preparation procedure with the application of hydrofluoric acid to remove silica, followed by acetolysis (Berglund and Ralska-Jasiewiczowa, 1986). A Lycopodium tablet (20,848 spores, produced by the University of Lund) was added to each sample to enable the calculation of pollen concentrations (Stockmarr, 1971). Pollen slides mounted with glycerin were analyzed using a light microscope at 400x and 1000x magnification and counted to a sum of arboreal pollen (AP) $>500$ grains. Two samples with pollen concentrations $<10,000$ grains $/ \mathrm{cm}^{3}$ were counted to $<500 \mathrm{AP}$ grains. Then, on the same slides, microscopic charcoal particles $(10-100 \mu \mathrm{m}$ in length) were counted at 200× magnification, alongwith Lycopodium spores, until a sum of 200 was reached (Finsinger and Tinner, 2005; Tinner and $\mathrm{Hu}$, 2003). Pollen grainswere identified with the assistance of the modern pollen slide collection of the Institute of Geoecology and Geoinformation of Adam Mickiewicz University in Poznań (Poland), as well as available keys and atlases (e.g. Beug, 2004; Moore et al., 1991). Percentages of pollen and spores were calculated relative to the sum of trees, shrubs, and herbs, excluding the pollen of wetland plants and dwarf shrubs. Charcoal accumulation rates (CHAR), expressed as charcoal pieces $/ \mathrm{cm}^{2} / \mathrm{yr}$, were calculated by multiplying charcoal concentrations (CHAC, pieces $/ \mathrm{cm}^{3}$ ) by the sediment accumulation rate for each analyzed level (Davis and Deevey, 1964).

\section{Testate amoebae}

Fossil testate amoebae were analyzed in subsamples taken at $1 \mathrm{~cm}$ intervals, whereas modern testate amoebae assemblages used to create the new transfer function were examined from surface moss samples. All of these samples were prepared by sieving and back-sieving (Booth et al., 2010). The testate amoebae were analyzed at 200-400x magnification, and a minimum of 150 tests per sample were performed whenever possible (Payne and Mitchell, 2008). The identification was performed at the 
highest possible taxonomical resolution based on the available literature (e.g. Grospietsch, 1958; Mazei and Tsyganov, 2006; Ogden and Hedley, 1980).

\section{Macrofossils}

For the analyses of plant macrofossils, contiguous samples of $3 \mathrm{~cm}^{3}$ (96 core samples) were analyzed at varying resolutions $(2-\mathrm{cm}$ resolution between $0 \mathrm{~cm}$ and 10 cm depth; 1-cm resolution below $10 \mathrm{~cm}$ depth). Each sample was wet sieved through a $0.2 \mathrm{~mm}$ mesh and macrofossils were identified under a binocular microscope using several keys (Birks, 2007; Grosse-Brauckmann, 1974, 1992; Laine et al., 2011; Tobolski, 2000) and reference specimens collected in Siberia. Additionally, macroscopic charcoal particles were counted wherever present.

\section{Bulk density and ash content}

Bulk density (BD; $\mathrm{g} \mathrm{cm}^{-3}$ ) and ash content (AC; \%) were measured to characterize the physical properties of the peat. BD was determined on the basis of $5-\mathrm{cm}^{3}$ subsamples, which were dried at $105^{\circ} \mathrm{C}$ for $24 \mathrm{~h}$ and then weighed. The dry weight $(\mathrm{g})$ was divided by the fresh sample volume $\left(\mathrm{cm}^{3}\right)$ (Chambers et al., 2011). AC for 94 duplicates was obtained by measuring the $\mathrm{LOI}_{550}$, where $\mathrm{LOI}_{550}$ is the loss on ignition at $550^{\circ} \mathrm{C}$ as defined by Heiri et al. (2001), and calculating using the equation $\mathrm{AC}=100 \%-$ $\mathrm{LOI}_{550}$.

\section{Numerical analyses}

A Hellinger-transformed testate amoebae community matrix was used as a response matrix (Legendre and Gallagher, 2001). Redundancy analyses (RDA) were employed to relate abiotic variables (water table, $\mathrm{pH}$ and conductivity) to biotic communities. The significance of the model, axes, and variables was tested using a Monte Carlo test with 999 permutations. Computations were performed in R 3.0.1 (Team, 2013), using the vegan package (Oksanen et al., 2011).

A quantitative water table reconstruction was developed using the local testate amoebae calibration data set from 68 moss samples collected in the Mukhrino peatland 
in 2012 and 2013. The training set was based on the relative abundance (percentage of entire community in a sample) and tested using common models in paleoecology, such as partial least squares (PLS), weighted averaging (WA), and weighted averaging partial least squares (WA-PLS) (Juggins and Birks, 2012). Prior to analysis, species present in less than three samples were removed. The best performing model was assessed using RMSEP, $\mathrm{R}^{2}$, and maximum bias criteria. Then, the model was used for the quantitative inference of the water table. Sample specific errors of the reconstruction were calculated using bootstrapping (Birks, 1995). Calculations were performed using C2 software (Juggins, 2003).

\section{Results and Interpretation}

\section{Ecology of testate amoebae}

A total of 64 testate amoebae taxa species and subspecies from 23 genera were identified at the Mukhrino mire. The most abundant taxa were Archerella flavum (20\%), Hyalosphenia papilio (15\%), Assulina muscorum (8\%), and Phryganella acropodia (7\%). The Shannon-Weiner diversity index ranged between 1.37-2.59. RDA revealed three clusters of species (Fig. 3A). Species composition shows that Assulina muscorum, A. seminulum, Trigonopyxis arcula, Trinema lineare, and Arcella catinus are correlated with low depth to water table (DWT), whereas Nebela carinata is an indicator of wet conditions. Hyalosphenia papilio occurs in plots with higher $\mathrm{pH}$ and conductivity (EC), and a moderately wet environment. Cyclopyxis arcelloides, Difflugia bacillifera, D. bacillariarum, D. globulosa, and Amphitrema wrightianum are related to lower $\mathrm{pH}$ and conductivity. Other species are located in the middle of the hydrological gradient. The full model explains $19.2 \%$ of the variation. DWT is stronglynegatively correlated with axis 1 (13.1\% variation explained), whereas $\mathrm{pH}$ and conductivityarenegatively correlated with axis 2 (4.9\% variation explained).The overallpermutation test (999 random permutations) showed that RDA was significant and axes 1 and 2 were highly significant (axis $1-p<0.001$, axis $2-p<0.002$ ). DWTwas the most significant variable $(p<0.001)$, followed by $\mathrm{pH}(p<0.005)$ and conductivity $(p<0.021)$.

\section{Testate amoeba calibration data set}


RDA revealed DWT as the most important variable for testate amoeba communities. Consequently, we used this variable for building the transfer function. The calibration tests show that the model performed well and generated acceptable levels of significance (Table 2).For the reconstruction, WA-PLS component 2 was selected, as it had the lowest RMSEP $\left(7.7 \mathrm{~cm}\right.$ ) and highest $\mathrm{R}^{2}(0.74)$ (Fig. 3B,C, Table 2). Subsequently, WA-PLS was applied for the quantitative estimation of the past water table dynamics.

\section{Chronology, sediment accumulation rate, bulk density and ash content}

Tenout of eleven ${ }^{14} \mathrm{C}$ dates provide a reliable age-depth model spanning the past $1300 \pm 30$ years, with an agreement index $\left(A_{\text {model }}\right)$ of $82 \%\left(A_{\text {model }}=60 \%\right.$ is the lowest critical value; Bronk Ramsey, 2008)(Fig. 2). Date Poz-59502 was excluded; its individual agreement of $0 \%$ decreased the $A_{\text {model }}$ below the critical value. The peat accumulation rates featured a close correspondence with peat properties. Those peat sections characterized by lower BD and AC have higher accumulation rates compared to sections with higher values for these physical parameters (Fig.2). Significant changes in bulk density were followed by changes in plant composition, as revealed by the macrofossil analysis (Fig. 4). The highest peat accumulation rate values occurred at ca. AD 19972012 (1.18-1.41 cm/yr) and ca. AD 1970-1980(0.89-0.9 cm/yr).Slightly lower accumulation occurred at ca. AD 1948-1970 (0.74-0.76 cm/yr) and ca. AD 1980-1997 (0.64-0.65 cm/yr). The period between ca. AD 1948 and 2012 featured the lowest BD and $\mathrm{AC}\left(0.05-0.09 \mathrm{~g} / \mathrm{cm}^{3}\right.$ and $1.3-2.6 \%$, respectively). During the oldest period (ca. AD $712-780$ ), peat accumulated at the rate of $0.18-0.23 \mathrm{~cm} / \mathrm{yr}$. During that interval, BD was highand fluctuated between $0.09-0.11 \mathrm{~g} / \mathrm{cm}^{3}$, with the exception of a distinct increase to $0.15 \mathrm{~g} / \mathrm{cm}^{3}$. AC rangedfrom 2.3 to3.9\%, with one distinct peak of $4.8 \%$ at ca. AD 737.The lowest rates of peat accumulation occurred between ca. AD 780 and AD1948(0.02-0.03 cm/yr). This interval is characterized by the highest values of BD $\left(0.09-0.19 \mathrm{~g} / \mathrm{cm}^{3}\right)$ and AC (2.7-6.9\%, peaking at ca. AD 1425). These high BD values were strongly related to the presence of E. vaginatum tissues and unidentified organic matter (Figs. 2 and 4). Very low rates of peat accumulation may also suggest some discontinuities during that period, and this prompts a very careful interpretation of charcoal accumulation rates (CHAR) for this section. 


\section{Peatland and forest development}

291

292

293

294

295

296

297

298

299

300

301

302

303

304

305

306

307

308

309

310

311

312

313

315

316

Four proxies, including plant macrofossils (Fig. 4), pollen (Fig.5), testate amoebae (Fig. 6), and charcoal (Fig. 7), were used to reconstruct the main developmental stages of the Mukhrino bog, fire history, and changes in the composition of the surrounding vegetation. These stages were delimited visually to five zones (MU1-5).

\section{MU1 (100-86 cm, ca. AD 712-780)}

At the beginning of the record, testate amoebae indicate a high water table. Archerella flavum dominates, accompanied by Hyalosphenia papilio, Heleopera sphagni, and Amphitrema wrightianum. This assemblage suggests pool Sphagnum communities. DWT oscillates around $12 \mathrm{~cm}$ (Fig. 6).

Macrofossils also indicate a relatively high groundwater table, as Sphagnum cf. balticum remains from sec. Cuspidata (Fig. 4) are typical for wet parts of the mire (e.g., carpets and lawns). Eriophorum vaginatum also suggests moist conditions (Hölzer, 2010).

The pollen spectra (Pinus sylvestris type, Pinus sibirica type, and Betula) reflect the presence of pine-birch forests, not only in this zone but in the entire profile, suggesting that vegetation composition varied little over the last 1300 years. Additional arboreal components of the forest include Populus, Salix, and Alnus in moist habitats, as well as "dark coniferous" forest, including Picea sect. Eupicea and Abies. In this zone, the pollen of Picea sect. Eupicea (probably P. abies ssp. obovata) reaches its maximum values (2.5-4.5\%). However, at the end of this zone (ca. AD 750) declining Picea percentages suggest a slight retreat of spruce.

CHAR reached 1935 pieces $/ \mathrm{cm}^{2} / \mathrm{yr}$ at ca. AD 730, then decreased. CHAC oscillated between 1945 and 8690 pieces $/ \mathrm{cm}^{3}$.

\footnotetext{
MU2 (86-58 cm, ca. AD 780-1882)
} 
In Zone MU2, the testate amoebae record features the disappearance of Archerella flavum and Sphagnum balticum. Concurrently, percentages of dry indicators, such as Arcella catinus, Trigonopyxis arcula, and Phryganella acropodia, increase. DWT increases gradually from approximately 13 to over $40 \mathrm{~cm}$.

Toward the top of this zone, Sphagnum magellanicum and Eriophorum vaginatum macrofossils indicate gradually decreasing bog surface wetness, and at the same time Sphagnum cf. balticum disappears abruptly Sphagnum magellanicum has a broad niche, but generally occurs at a water table depth of ca. $24 \mathrm{~cm}$ (Hölzer, 2010). Wood and Ericaceae remains appear in this zone, suggesting a lower water table and the development of local shrub communities (Fig. 4).

The pollen assemblages in Zone MU2 are similar to those of the previous zone. A

\section{MU3 (58-40 cm, ca. AD 1882-1970)}

Arcella catinus percentages decline considerably in Zone MU3, whereas other dry indicators, such as Trigonopyxis arcula and Phyganella acropodia, remain relative abundant. Nebela militaris first becomes abundant in this zone. This species usually indicates a higher water table than T. arcula or P. acropodia, but the habitat was still quite dry, as indicated by the abundance of Sphagnum fuscum. DWT indicates a gradually increasing water table.

An abrupt transition between Sphagnum magellanicum and S. fuscum took placeca. AD 1900; this shift was accompanied by an increase in the percentages of Ericaeae, as well as higher wood remains.

In MU3, Artemisia reaches its highest percentages in the profile (ca. AD 18821966; 3.5-5.5\%),possibly reflecting higher landscape openness. Spheroidal 
carboniferous particles (SCP) appear in this zone, suggesting coal burning in the surrounding are or distant transport from industrialized areas (Swindles et al., 2015).

CHAC decreased from 7716to 616pieces $/ \mathrm{cm}^{3}$, while CHAR ranged between264 and 637 pieces/cm²/year. Macroscopic charcoal (particles $>200 \mu \mathrm{m}$ ) at the depth corresponding to ca. AD 1900 indicate local fires (Fig. 4).

\section{MU4 (40-22.5 cm, ca. AD 1970-1994)}

In Zone MU4 testate amoebae assemblages, Nebela militaris continues to indicate a low water table, but the reconstructed water depth shows a gradual increase, reaching a value of approximately $9 \mathrm{~cm}$.

At this time the bog was dominated by Sphagnum fuscum (as high as 90\%). Polytrichum first occurs in MU4, suggesting a low water table and hummock development. Pinus bark suggests the presence of pines in the hummocky dwarf shrubSphagnum communities. Ericaceae and wood remains decreased gradually, perhaps reflecting a higher water table.

Pollen data in MU4 feature the highest value of Rubus chamaemorus (max. 2\%); its presence suggests the development of a hummock. SCP values increase after ca. AD 1985, likely signaling the increasing industrialization in the region (Swindles et al., 2015). CHAR increased abruptly to 6899 pieces $/ \mathrm{cm}^{2} /$ yrin ca. AD 1975. At the same time, CHACwas 7726 pieces $/ \mathrm{cm}^{3}$.

\section{MU5 (22.5-0 cm, ca. AD 1994-2012)}

The macrofossil record in Zone MU5 suggests a low water table, as indicated by the stable values for Sphagnum fuscum and Polytrichum remains, although Hyalosphenia elegans, H. papilio, and Archerella flavum point to higher habitat wetness. Other species, such as Nebela militaris, Phryganella acropodia, and Trigonopyxis arcula, decreased in this period.

A decrease in the Rubus chamaemorus pollen percentages suggests the retreat of hummock habitats from the coring location. 
SCP records reveal increased coal burning between AD1994 and AD 2000 (max. 267 particles $/ \mathrm{cm}^{2} / \mathrm{yr}$ ). CHAR and CHAC reached maximum values of $914 \mathrm{pieces} / \mathrm{cm}^{2} / \mathrm{yr}$ and CHAC of 759 pieces $/ \mathrm{cm}^{3}$,respectively, with a decreasing trend toward the top of the zone.

\section{Discussion}

\section{Calibration data set and ecology of testate amoebae}

Numerous studies have analyzed testate amoebae ecology in various biogeographical settings in Russia (Bobrov et al., 1999; Bobrov et al., 2002; Bobrov et al., 2003; Bobrov et al., 2013; Mazei and Embulaeva, 2009; Mazei et al., 2009; Mazei et al., 2007; Payne et al., 2012; Tsyganov et al., 2015), but there have been few such studies in Siberian peatlands (Bobrov et al., 2002; Kurina et al., 2010; Mazei and Kabanov, 2008). Our calibration study at Mukhrino mire illustrates the relationship between testate amoebae community composition and several environmental parameters. The redundancy analysis demonstrated the importance of water table depth, which is consistent with findings from other regions (Lamentowicz and Mitchell, 2005; Qin et al., 2013; Tolonen et al., 1994; Van Bellen et al., 2014). Acidity was a less important parameter, perhaps due to the limited range of the sampled habitats. The overall species composition of testate amoebae at Mukhrino mire was not different from those described in Europe or North America (Booth, 2007; Charman et al., 2007). The most abundant species in wet parts of the gradient are the mixotrophic species Hyalosphenia papilio and Archerella flavum, as well as Nebela carinata. In Sphagnum fuscum hummocks, which were the driest part of the gradient, Assulina muscorum, Trigonopyxis arcula, and Arcella catinus dominated.

A characteristic feature of this Siberian peatland is that minerotrophic species are absent, as the habitat is purely organic and very acidic. An advantage of our study is that the training set was taken from a pristine bog, large enough to exclude any bordering effect, and then applied to a core also representing pristine conditions. In Europe, in contrast, testate amoebae training sets are often collected from raised bogs that have experienced disturbance, possibly biasing reconstructions derived from them. We think that the new calibration data set from Siberia is important for its inferences concerning 
paleohydrological dynamics in order to better assess the processes that drive carbon accumulation. In our application of the testate amoebae transfer function to the 1300year-long core from Mukhrino mire, the composition of the modern communities was similar to that of the fossil assemblages, and thus the transfer function could be used to reconstruct past hydrological conditions with confidence (Juggins and Birks, 2012).

\section{Hydrology, fires, and forests in western Siberia}

As the Mukhrino mire record is the first from Siberia in which the paleohydrology of the last millennium has been quantitatively reconstructed based on amoderncalibration training set, we can only relate our findings to other records from other parts of Eurasia. The dry stage at AD 780-1882 in the Mukhrino profile is similar to dry intervals described in other studies from central and eastern Europe (Gałka et al., 2014; Lamentowicz et al., 2009). In the case of Polish sites, however, unstable hydrological conditions rather than permanent drought prevailed(Marcisz et al., 2015). This may suggest that the drought increased in intensity from west to east, being most severe in continental areas like western Siberia. The recent study of Feurdean et al. (2015) provides a regional summary of paleohydrological change in bogs of central and eastern Europe and supports the interpretation of the LIA as dry in eastern sites and contrastingly wet in western sites.

Under the continental conditions of western Siberia, the influence of climate on peatlands during the LIA may have been different than was the case in oceanic western Europe. In western Europe, wet conditions may have arisen due to increased summer precipitation and a change in air circulation patterns (Magny et al., 2010; Magny et al., 2008). The growth of alpine glaciers during the LIA is consistent with higher moisture(Holzhauser et al., 2005), and the only existing high-resolution bog record from the eastern Swiss Alps revealed a wet trend during the LIA (van der Knaap et al., 2011).Similarly, the peatlands of the British Isles indicate moist conditions during the LIA (Charman et al., 2006). Changes in temperature may also be involved in the shifts observed in the Mukhrino mire record. Cool temperatures could have limited peat accumulation, generating changes in our proxies that are suggestive of a dry phase. The extensive carbon accumulation database from northern latitudes reveals such a trend during the LIA, with carbon sequestration rate declining during the transition from the MWP to the LIA. This was probably because the LIA featured the combination of lower 
temperatures and increased cloudiness, suppressing net primary productivity (Charman et al., 2013). However, given the distance between western Europe and Siberia, it may be the case that the climatic causes of dry conditions during the LIA at eastern sites were different from those operating further to the west.

Because our study is based on a single core, alternative explanations for the peatland development and peat accumulation changes should be taken into account. The patterns that we have observed could also be related to autogenic development of the peatland itself. Peat vegetation forms various distinct microhabitats in the Mukhrino mire, including very wet pools with open water, flarks overgrown by pines (so-called ryam forest, which is typical for raised bogs in western Siberia), and Sphagnum lawns. Changes in the water table may have been caused by migration (or alternative development) of those microhabitats on the peatland surface. Moreover, because the core was sampled on the margin of the flark, it is plausible that what we have interpreted as low water table conditions is instead related to the change of surface microhabitats from a pool to the flark (Zobel, 1988). It may be the case that the observed hydrological shifts are related to both internal feedbacks (Swindles et al., 2012) and allogenic forcing (Barber, 1981); additional work at Mukhrino is needed to determine the relative importance of these factors.

Fire is a key process that influences the physical and biological structure of boreal forests (Stocks et al., 2001). Wildfires affect all characteristics of the ecosystem, including species composition and diversity, biogeochemical cycles and energy flows, and carbon cycling (van Bellen et al., 2012). Wildfires in boreal ecosystems are highly dependent not only on climatic conditions (such as heat waves or hydrological stress), but also on forest management and the accumulation of woody debris (Gennaretti et al. (2013). Our study revealed a lack of dramatic shifts in vegetation in the Mukhrino area over the last 1300 years. Pinus sylvestris, P. sibirica, and Betula were the dominant taxa, with Alnus, Picea, Populus and Abies as additional components (Fig. 5). However, one intriguing change is the decline of Picea (probably Picea abies ssp. obovata) at AD 750, a time of stable hydrological conditions and decreasing fire activity. Picea abies is thought to be poorly adapted to fire and drought due to its relatively thin bark and shallow root system (Niklasson et al., 2002; Zackrisson, 1977). Thus, the parallel declines in Picea and CHAR in the Mukhrino record are somewhat unexpected, although paleoecological 
studies from Fennoscandia, where this phenomenon has been widely investigated, also feature unclear findings (Bradshaw et al., 2010). Several studies reported the expansion of P. abies during times of increased fire activity (Barnekow et al., 2008; Brown and Giesecke, 2014; Carcaillet et al., 2007; Rosén and Hammarlund, 2007), but others found that fire decreased prior to P. abies expansion (Tryterud, 2003;0hlson et al., 2011). Additional studies spanning longer time scales are needed to better understand the relationship between $P$. abies and fire in Siberia and other boreal regions.

The charcoal record from Mukhrino mire is of particular relevance given the significant amount of carbon emitted by burning peatlands (French et al., 2004; Kasischke et al., 2005; Turetsky et al., 2015). The Mukhrino profile featured maximum CHAR values at ca. AD 1975 and two smaller peaks (at ca. AD 1984 and AD 2000), indicating higher fire activity during the last 60 years than at any point in the last millennium (Fig. 7). This shift may be linked with the fast development of the nearby city of Khanty-Mansiysk, which saw fast population growth starting in the 1950s. The finding of oil and gas in the region had a major impact on the development of local industry and caused a rapid influx of population from 18,000 in 1956 to 1,478,000 in 2006 (official data from the Khanty-Mansi Autonomous Okrug). This substantial increase in population not only had an impact on the development of the city itself, but also contributed to the pressure on the environment in the region. Human penetration into forests increased, contributing to higher fire activity during recent decades. A key change was the completion of abridge across the Irtysh River in around 2005, as only a few hunters visited the Mukhrino area prior to this improved access. Moreover, the nearest oil fields, located 100-200 km away, started to develop on the left bank of the Irtysh River only 5-7 years ago. Thus it appears that fires in the Mukhrino area have experienced little human influence during most of the last 1300 years. A similar increase in fire activity over the past 60 years is noticeable in boreal forests of Canada (Stocks et al., 2002).

An alternative explanation for the observed increase in fire is that changes in climate may have caused increased burning and extended fire seasons during the last half of the twentieth century in Canada and Siberia(Dale et al., 2001; Kirilenko and Sedjo, 2007; Wotton and Flannigan, 1993). Barichivich et al. (2014) showed that rapid summer warming since the 1980s is a significant driver of increased evapotranspiration, 
which affects summer drought severity in the northern latitudes. In turn, drier conditions may lead to higher intensity of fires and longer growing seasons in Siberia and other boreal regions (Flannigan et al. (2013).The Arctic Oscillation (AO) also appears to influence the inter-annual variability of fire in Siberia, with higher fire activity during the positive phase of the AO (Balzter et al., 2005, 2007; Sukhinin et al., 2004). Our record provides data that can be related to AO as well as to human activity, however, we need more peat profiles from W Siberia to be sure that this is climatic forcing.

\section{Acknowledgments}

We acknowledge the support of the International Network for Terrestrial Research and Monitoring in the Arctic INTERACT that funded the project: "Functioning of Siberian mire ecosystems and their response to climate changes" Project acronym: CliMireSiber (PI: Fatima Laggoun-Defarge). We were also supported by RE-FIRE SCIEX project 12.286 and grant PSPB-013/2010 from Switzerland through the Swiss Contribution to the enlarged European Union, as well as by grant 2011/01/D/ST10/02579 from the National Centre of Science (NCN).This study is a contribution to the Virtual Institute of Integrated Climate and Landscape Evolution (ICLEA) of the Helmholtz Association. We are grateful to Christopher Bronk Ramsey for giving us important suggestions considering age-depth modeling and to Monika Kołaczek for her useful remarks. Two anonymous reviewers and associate editor Wyatt Osvald are thanked for important comments that helped to improve the manuscript.

\section{Captions to figures}

Figure 1. Map of Eurasia showing the location of Mukhrino mire and indicating the range of boreal forests.

Figure 2. Age-depth model for the Mukhrino mire core with bulk density and ash content. Dates are listed on the left, along the depth scale (see Table 1), each of these are presented with individual agreement of modeled and calibrated date, which is placed in 
square brackets (for details see Bronk Ramsey (2008)). Abbreviations: Poz - laboratory code of Poznań Radiocarbon Laboratory, TPS - total pollen sum.

Figure 3. Result of the redundancy analysis (RDA) of testate amoeba communities (A) and measured environmental variables $(\mathrm{pH}$ and depth to the water table - DWT) from modern surface samples collected from Mukhrino mire, (B) observed vs. predicted model, and $(\mathrm{C})$ residuals of the weighted averaging partial least squares model with bootstrap cross validation (WA-PLSboot).

Species abbreviations: AMP WRI - Amphitrema wrightianum, ARC ARE - Arcella arenaria, ARC ART - Arcella artocrea, ARC BAT - Arcella bathystoma, ARC CAT - Arcella catinus, ARC DIS - Arcella discoides, ARC SP - Arcella sp., ARCH FLA - Archerella flavum, ARC HEM - Arcella hemisphaerica, ARGSP - Argynnia sp., ASS MUS - Assulina muscorum, ASS SCA - Assulina scandinavica, ASS SEM - Assulina seminulum, BULIND - Bullinularia indica, CEN AER - Centropyxis aerophila, CEN ACU - Centropyxis aculeata, CEN ORBCentropyxis orbicularis, CEN CAS - Centropyxis cassis, CEN PLA - Centropyxis platystoma, CEN SP - Centropyxis sp., COR DUB - Corythion dubium, CRY OVI - Cryptodifflugia oviformis,CYC ARC-Cyclopyxis arcelloides, CYCKAH - Cyclopyxis kahli, CYPSP Cyphoderia sp., CYP AMP - Cyphoderia ampulla, DIFBACC -Difflugia baccillariarum, DIFBACI - Difflugia bacilifera,DIFBRE - Difflugia brevicola, DIFGLO - Difflugia globulosa, DIF LAN - Difflugia langeniformis, DIF LEI - Diffluga leidyi, DIF LIM - Difflugia limnetica, DIFOBL - Difflugia oblonga, DIFURC - Difflugia urceollata, DIFSP - Difflugia sp., EUGCIL Euglypha ciliata, EUG COM- Euglypha compressa, EUGCOMGLA - Euglypha compressa glabra, EUG CRI -Euglypha cristata, EUG ROT -Euglypha rotunda, EUGSTR - Euglypha strigosa, EUG TUB - Euglypha tuberculata, EUGSP - Euglypha species, HEL PET Heleopera petricola, HEL SPH - Heleopera sphagni, HEL ROS - Heleopera rosea, HYAELE Hyalosphenia elegans, HYA PAP - Hyalosphenia papilio, NEB CAR - Nebela carinata, NEB MIL - Nebela militaris, NEB TIN - Nebela tincta, PHRACR - Phryganella acropodia, PHR PAR - Phryganella paradoxa, PHYGRI - Physochila griseola,PLA SPI - Placocista spinosa, PSE GRA - Pseudodifflugia gracilis, SPH LEN - Sphenoderia lenta, TRI ARC - Trigonopyxis arcula, TRI SP - Trigonopyxis sp., TRINENC - Trinema enchelis, TRIN LIN - Trinema lineare. 
Figure 4. Plant macrofossil diagram for Mukhrino mire. Abbreviations: UOM unidentified organic matter. Non-\% variables are provided as absolute values; , 5 times exaggeration is presented as white silhouette.

565 Figure 5. Pollen percentage diagram for Mukhrino mire, 5 times exaggeration is 566 presented as white silhouette. SCP AR - spheroidal carbonaceous particles (SCPs) 567 accumulation rate.

568 Figure 6. Testate amoebae percentage diagram for Mukhrino mire, 5 times exaggeration 569 is presented as white silhouette. WA PLS Comp 2 (weighted averaging partial least 570 squares component 2) - model used for the DWT (depth to the water table) quantitative 571 reconstruction.

572 Figure 7. Summary diagram for Mukhrino mire with comparison of testate amoebae573 based water table reconstruction (DWT), charcoal influx (CHAR), and charcoal 574 concentration (CHAC). WA PLS Comp 2 (weighted averaging partial least squares 575 component 2) - model used for the DWT (depth to the water table) quantitative 576 reconstruction.

\section{Tables}

579 Table 1. Results of radiocarbon dating from the Mukhrino profile. Abbreviations: Poz 580 laboratory code of the Poznań Radiocarbon Laboratory (Poland).

581 Table 2.Transfer function performance statistics. The best model is WAPLS Component 5822. 
Ahmed, M., Anchukaitis, K.J., Asrat, A., Borgaonkar, H.P., Braida, M., Buckley, B.M., Büntgen, U., Chase, B.M., Christie, D.A., Cook, E.R., Curran, M.A.J., Diaz, H.F., Esper, J., Fan, Z.-X., Gaire, N.P., Ge, Q., Gergis, J., González-Rouco, J.F., Goosse, H., Grab, S.W., Graham, N., Graham, R., Grosjean, M., Hanhijärvi, S.T., Kaufman, D.S., Kiefer, T., Kimura, K., Korhola, A.A., Krusic, P.J., Lara, A., Lézine, A.M., Ljungqvist, F.C., Lorrey, A.M., Luterbacher, J., Masson-Delmotte, V., McCarroll, D., McConnell, J.R., McKay, N.P., Morales, M.S., Moy, A.D., Mulvaney, R., Mundo, I.A., Nakatsuka, T., Nash, D.J., Neukom, R., Nicholson, S.E., Oerter, H., Palmer, J.G., Phipps, S.J., Prieto, M.R., Rivera, A., Sano, M., Severi, M., Shanahan, T.M., Shao, X., Shi, F., Sigl, M., Smerdon, J.E., Solomina, O.N., Steig, E.J., Stenni, B., Thamban, M., Trouet, V., Turney, C.S.M., Umer, M., van Ommen, T., Verschuren, D., Viau, A.E., Villalba, R., Vinther, B.M., von Gunten, L., Wagner, S., Wahl, E.R., Wanner, H., Werner, J.P., White, J.W.C., Yasue, K., Zorita, E., 2013. Continental-scale temperature variability during the past two millennia. Nature Geoscience 6, 339-346.

Balzter, H., Gerard, F.F., George, C.T., Rowland, C.S., Jupp, T.E., McCallum, I., Shvidenko, A., Nilsson, S., Sukhinin, A., Onuchin, A., Schmullius, C., 2005. Impact of the Arctic Oscillation pattern on interannual forest fire variability in Central Siberia. Geophysical Research Letters 32, L14709. Barber, K.E., 1981. Peat stratigraphy and climatic change. A palaeoecological test of the theory of cyclic bog regeneration. A.A. Balkema, Rotterdam.

Barichivich, J., Briffa, K., Myneni, R., Schrier, G., Dorigo, W., Tucker, C., Osborn, T., Melvin, T., 2014. Temperature and Snow-Mediated Moisture Controls of Summer Photosynthetic Activity in Northern Terrestrial Ecosystems between 1982 and 2011. Remote Sensing 6, 1390-1431. Beilman, D.W., MacDonald, G.M., Smith, L.C., Reimer, P.J., 2009. Carbon accumulation in peatlands of West Siberia over the last 2000 years. Global Biogeochemical Cycles 23.

Berglund, B.E., Ralska-Jasiewiczowa, M., 1986. Pollen analysis and pollen diagrams, in: Berglund, B.E. (Ed.), Handbook of Holocene Paleoecology and Paleohydrology. Wiley \& Sons Ltd., Chichester-Toronto, pp. 455-484.

Beug, H.-J., 2004. Leitfaden der Pollenbestimmung für Mitteleuropa und angrenzende Gebiete. . Verlag Dr. Friedrich Pfeil, München.

Birks, H.H., 2007. Plant macrofossil introduction, in: Elias, S.A. (Ed.), Encyclopedia of Quaternary Science. Elsevier, Amsterdam, pp. 2266-2288.

Birks, H.J.B., 1995. Quantitative Palaeoenvironmental Reconstructions, in: Maddy, D., Brew, J.S. (Eds.), Statistical Modelling of Quaternary Science Data. Quaternary Research Associacion, Cambridge, pp. 161-254.

Bleuten, W., Filippov, I., 2008. Hydrology of mire ecosystems in central West Siberia: the Mukhrino field station, in: Glagolev, M.V., Lapshina, E.D. (Eds.), Transactions of UNESCO Department of Yugorsky State University "Dynamics of Environment and Global Climate Change".

Blundell, A., Barber, K., 2005. A 2800-year palaeoclimatic record from Tore Hill Moss, Strathspey, Scotland: the need for a multi-proxy approach to peat-based climate reconstructions. Quaternary Science Reviews 24, 1261-1277.

Blundell, A., Charman, D.J., Barber, K., 2008. Multiproxy late Holocene peat records from Ireland: towards a regional palaeoclimate curve. Journal of Quaternary Science 23, 59-71. Bobrov, A.A., Charman, D.j., Warner, B.G., 1999. Ecology of Testate Amoebae (Protozoa: Rhizopoda) on Peatlands in Western Russia with special attention to Niche Separation in closely Related Taxa. Protist 150, 125-136.

Bobrov, A.A., Charman, D.J., Warner, B.G., 2002. Ecology of Testate Amoebae from Oligotrophic Peatlands: Specific Features of Polytypic and Polymorphic Species. Biology Bulletin of the Russian Academy of Sciences 29, 605-617.

Bobrov, A.A., Siegert, C., Andreev, A.A., Schirrmeister, L., 2003. Testaceans (Protozoa: Testacea) in Quaternary Permafrost Sediments of Bykovsky Peninsula, Arctic Yakutia. Biology Bulletin 30, 191-206. 
Bobrov, A.A., Wetterich, S., Beermann, F., Schneider, A., Kokhanova, L., Schirrmeister, L., Pestryakova, L.A., Herzschuh, U., 2013. Testate amoebae and environmental features of polygon tundra in the Indigirka lowland (East Siberia). Polar Biology 36, 857-870.

Booth, R.K., 2007. Testate amoebae as proxies for mean annual water-table depth in Sphagnumdominated peatlands of North America. Journal of Quaternary Science 23, 43-57.

Booth, R.K., Lamentowicz, M., Charman, D.J., 2010. Preparation and analysis of testate amoebae in peatland paleoenvironmental studies. Mires and Peat 7 (2010/11), 1-7.

Booth, R.K., Notaro, M., Jackson, S.T., Kutzbach, J.E., 2006. Widespread drought episodes in the western Great Lakes region during the past 2000 years: Geographic extent and potential mechanisms. Earth and Planetary Science Letters 242, 415-427.

Booth, R.K., Sullivan, M.E., Sousa, V.A., 2008. Ecology of testate amoebae in a North Carolina pocosin and their potential use as environmental and paleoenvironmental indicators. Ecoscience 15, 277-289.

Borren, W., Bleuten, W., Lapshina, E.D., 2004. Holocene peat and carbon accumulation rates in the southern taiga of western Siberia. Quaternary Research 61, 42- 51.

Bradshaw, R.H.W., Lindbladh, M., Hannon, G.E., 2010. The role of fire in southern Scandinavian forests during the late Holocene. International Journal of Wildland Fire 19, 1040-1049. Bronk Ramsey, C., 2008. Deposition models for chronological records. Quaternary Science Reviews 27, 42-60. Chambers, F.M., Beilman, D.W., Yu, Z., 2011. Methods for determining peat humification and for quantifying peat bulk density, organic matter and carbon content for palaeostudies of climate and peatland carbon dynamics. Mires and Peat 7, 1-10.

Charman, D., Blundell, A., MEMBERS, A., 2007. A new European testate amoebae transfer function for palaeohydrological reconstruction on ombrotrophic peatlands. Journal of Quaternary Science 22, 209-221.

Charman, D.J., 2002. Peatlands and environmental change. John Wiley \& Sons, Chichester. Charman, D.J., Beilman, D.W., Blaauw, M., Booth, R.K., Brewer, S., Chambers, F.M., Christen, J.A., Gallego-Sala, A., Harrison, S.P., Hughes, P.D.M., Jackson, S.T., Korhola, A., Mauquoy, D., Mitchell, F.J.G., Prentice, I.C., van der Linden, M., De Vleeschouwer, F., Yu, Z.C., Alm, J., Bauer, I.E., Corish, Y.M.C., Garneau, M., Hohl, V., Huang, Y., Karofeld, E., Le Roux, G., Loisel, J., Moschen, R., Nichols, J.E., Nieminen, T.M., MacDonald, G.M., Phadtare, N.R., Rausch, N., Sillasoo, Ü., Swindles, G.T., Tuittila, E.S., Ukonmaanaho, L., Väliranta, M., van Bellen, S., van Geel, B., Vitt, D.H., Zhao, Y., 2013. Climate-related changes in peatland carbon accumulation during the last millennium.

Biogeosciences 10, 929-944.

Charman, D.J., Blundell, A., Chiverrell, R.C., Hendon, D., Langdon, P.G., 2006. Compilation of nonannually resolved Holocene proxy climate records: stacked Holocene peatland palaeo-water table reconstructions from northern Britain. Quaternary Science Reviews 25, 336-350.

Dale, V.H., Joyce, L.A., McNulty, S., Neilson, R.P., Ayres, M.P., Flannigan, M.D., Hanson, P.J., Irland, L.C., Lugo, A.E., Peterson, C.J., Simberloff, D., Swanson, F.J., Stocks, B.J., Wotton, B.M., 2001. Climate change and forest disturbances. Bioscience 51, 723-734.

Davis, M.B., Deevey, E.S.J., 1964. Pollen accumulation rates: estimates from late-glacial sediment of Roger Lake. Science 145, 1293-1295.

Dise, N.B., 2010. Peatland response to global change. Science 326, 810-811. Elger, K., Opel, T., Topp-Jřrgensen, E., Rasch, M., 2012. INTERACT Station Catalogue. Aarhus University.

Feurdean, A., Galka, M., Kuske, E., Tantau, I., Lamentowicz, M., Florescu, G., Liakka, J., Hutchinson, S.M., Mulch, A., Hickler, T., 2015. Last Millennium hydro-climate variability in Central-Eastern Europe (Northern Carpathians, Romania). The Holocene 25, 1179-1192.

Fiałkiewicz-Kozieł, B., Kołaczek, P., Michczyński, A., Piotrowska, N., 2015. The construction of a reliable absolute chronology for the last two millennia in an anthropogenically disturbed peat bog: Limitations and advantages of using a radio-isotopic proxy and age-depth modelling. Quaternary Geochronology 25, 83-95. 
Filippov, I.V., Lapshina, E.D., 2008. Peatland unit types of lake-bog systems in the Middle Priob'ie (Western Siberia), in: ED, G.M.a.L. (Ed.), Transactions of UNESCO Department of Yugorsky State University "Dynamics of Environment and Global Climate Change, pp. 115-124

Finsinger, W., Tinner, W., 2005. Minimum count sums for charcoal-concentration estimates in pollen slides: Accuracy and potential errors. Holocene 15, 293-297.

Flannigan, M., Cantin, A.S., de Groot, W.J., Wotton, M., Newbery, A., Gowman, L.M., 2013. Global wildland fire season severity in the 21st century. Forest Ecology and Management 294, 54-61. French, N.H.F., Goovaerts, P., Kasischke, E.S., 2004. Uncertainty in estimating carbon emissions from boreal forest fires. Journal of Geophysical Research: Atmospheres 109, D14S08. Gałka, M., Miotk-Szpiganowicz, G., Goslar, T., Jęśko, M., van der Knaap, W.O., Lamentowicz, M., 2013. Palaeohydrology, fires and vegetation succession in the southern Baltic during the last 7500 years reconstructed from a raised bog based on multi-proxy data. Palaeogeography, Palaeoclimatology, Palaeoecology 370, 209 - 221.

Gałka, M., Tobolski, K., Górska, A., Milecka, K., Fiałkiewicz-Kozieł, B., Lamentowicz, M., 2014. Disentangling the drivers for the development of a Baltic bog during the Little Ice Age in northern Poland. Quaternary International 328-329, 323-337.

Gennaretti, F., Arseneault, D., Bégin, Y., De Deyn, G., 2013. Millennial stocks and fluxes of large woody debris in lakes of the North American taiga. Journal of Ecology, n/a-n/a. Grospietsch, T., 1958. Wechseltierchen (Rhizopoden). Kosmos Verlag, Stuttgart. Grosse-Brauckmann, G., 1974. Über pflanzliche Makrofossilien mitteleuropäischer Torfe. II. Weitere Reste (Früchte und Samen, Moose u.a.) und ihre Bestimmungsmöglichkeiten - On plant macrofossils in central European peat. II. Other remnants (e.g. fruits and seeds, mosses) and possibilities for their identification. Telma 4, 51-117 (in German).

Grosse-Brauckmann, G., 1992. Über pflanzliche Makrofossilien mitteleuropäischer Torfe. III. Früchte, Samen und einige Gewebe (Fotos von fossilen Pflanzenresten) - On plant macrofossils in central European peat. III. Fruits, seeds and some tissues (photos of fossil plant remains). Telma 22, 53-102 (in German).

Heiri, O., Lotter, A.F., Lemcke, G., 2001. Loss on ignition as a method for estimating organic and carbonate content in sediments: reproducibility and comparability of results. Journal of Paleolimnology 25, 101-110.

Hendon, D., Charman, D.J., 2004. High-resolution peatland water-table changes for the past 200 years: the influence of climate and implications for management. The Holocene 14, 125-134. Hölzer, A., 2010. Die Torfmoose Südwestdeutschlands und der Nachbargebiete. Weissdorn Verlag Jena, Jena.

Holzhauser, H., Magny, M., Zumbuhl, H.J., 2005. Glacier and lake-level variations in west-central Europe over the last 3500 years. The Holocene 15, 789-801.

Hua, Q., Barbetti, M., Rakowski, A.Z., 2013. Atmospheric Radiocarbon for the Period 1950-2010. Radiocarbon 55, 2059-2072.

Jones, P.D., Mann, M.E., 2004. Climate over past millennia. Rev. Geophys., 42 pp. Juggins, S., 2003. C2 User guide. Software for ecological and palaeoecological data analysis and visualisation. University of Newcastle, Newcastle upon Tyne, UK. Juggins, S., Birks, J., 2012. Quantitative Environmental Reconstructions from Biological Data, in: Birks, H.J.B., Lotter, A.F., Juggins, S., Smol, J.P. (Eds.), Tracking Environmental Change Using Lake Sediments. Developments In Paleoenvironmental Research. Springer, pp. 431-494. Kaislahti Tillman, P., Holzkämper, S., Kuhry, P., Sannel, A.B.K., Loader, N.J., Robertson, I., 2010. Long-term climate variability in continental subarctic Canada: A 6200-year record derived from stable isotopes in peat. Palaeogeography, Palaeoclimatology, Palaeoecology 298, 235-246.

Kasischke, E.S., Hyer, E.J., Novelli, P.C., Bruhwiler, L.P., French, N.H.F., Sukhinin, A.I., Hewson, J.H., Stocks, B.J., 2005. Influences of boreal fire emissions on Northern Hemisphere atmospheric carbon and carbon monoxide. Global Biogeochemical Cycles 19, GB1012. Kirilenko, A.P., Sedjo, R.A., 2007. Climate change impacts on forestry. Proc Natl Acad Sci U S A 104, 19697-19702. 
Kremenetski, K.V., Velichko, A.A., Borisova, O.K., MacDonald, G.M., Smith, L.C., Frey, K.E., Orlova, L.A., 2003. Peatlands of the Western Siberian lowlands: current knowledge on zonation, carbon content and Late Quaternary history. Quaternary Science Reviews 22, 703-723.

Kurina, I.V., Preis, Y.I., Bobrov, A.A., 2010. Testate amoebae inhabiting middle taiga bogs in Western Siberia. Biology Bulletin 37, 357-362.

Laine, J., Harju, P., Timonen, T., Laine, A., Tuittila, E.S., Minkkinen, K., Vasander, H., 2011. The Intricate Beauty of Sphagnum Mosses e a Finnish Guide to Identification. University of Helsinki Department of Forest Sciences Publications, Helsinki.

Lamentowicz, M., Cedro, A., Gałka, M., Miotk-Szpiganowicz, G., Mitchell, E.A.D., Pawlyta, J., Goslar, T., 2008. Last millennium palaeoenvironmental changes from a Baltic bog (Poland) inferred from stable isotopes, pollen, plant macrofossils and testate amoebae. Palaeogeography, Palaeoclimatology, Palaeoecology 265, 93-106.

Lamentowicz, M., Gałka, M., Pawlyta, J., Lamentowicz, Ł., Goslar, T., Miotk-Szpiganowicz, G., 2011. Climate change and human impact in the southern Baltic during the last millennium reconstructed from an ombrotrophic bog archive. Studia Quaternaria 28, 3-16.

Lamentowicz, M., Milecka, K., Gałka, M., Cedro, A., Pawlyta, J., Piotrowska, N., Lamentowicz, Ł., van der Knaap, W.O., 2009. Climate- and human-induced hydrological change since AD 800 in an ombrotrophic mire in Pomerania (N Poland) tracked by testate amoebae, macro-fossils, pollen, and tree-rings of pine. Boreas 38, 214-229.

Lamentowicz, M., Mitchell, E.A.D., 2005. The ecology of testate amoebae (Protists) in Sphagnum in north-western Poland in relation to peatland ecology. Microbial ecology 50, 48-63.

Lapshina, E.D., Plogova, N.N., 2011. Spatial Dynamics of peat growth and carbon accumulation in sphagnum bogs (Boreal West Siberia), West Siberian Peatlands and Carbon Cycle: past and present. Proceedings of the Third International Field Symposium Khanty-Mansiysk, June 27 July 5, 2011.

Lapshina, E.D., Pologova, N.N., E.Ya., M., 2001. Pattern of development and carbon accumulation in homogenous Sphagnum fuscum-peat deposit on the south of West Siberia, in: Vasiliev, S., Titlyanova, A., Velochko, A. (Eds.), West Siberian Peatlands and Carbon Cycle: past and present. Proceedings of International Field Symposium, Noyabrsk August 18 - 22, 2001, pp. 101-104. Lavoie, C., Pellerin, S., 2007. Fires in temperate peatlands (southern Quebec): Past and recent trends. Canadian Journal of Botany 85, 263-272.

Legendre, P., Gallagher, E.D., 2001. Ecologically meaningful transformations for ordination of species data. Oecologia 129, 271-280.

Liss, O.L., Abramova, K.I., L.I.Avetov, 2001. Bog ecosystems of West Siberia and their environmental importance. Tula: Publishing house 'Grif i Ko'.

Loisel, J., Yu, Z., 2013. Surface vegetation patterning controls carbon accumulation in peatlands. Geophysical Research Letters 40, 5508-5513.

Loisel, J., Yu, Z., Beilman, D., Philip, C., Jukka, A., David, A., Andersson, S., Fiałkiewicz-Kozieł, B., Barber, K., Belyea, L., Bunbury, J., Chambers, F., Charman, D., de Vleeschouwer, F., Finkelstein, S., Garneau, M., Hendon, D., Holmquist, J., Hughes, P., Jones, M., Klein, E., Kokfelt, U., Korhola, A., Kuhry, P., Lamarre, A., Lamentowicz, M., Large, D., Lavoie, M., MacDonald, G., Magnan, G., Gałka, M., Mathijssen, P., Mauquoy, D., McCarroll, J., Moore, T., Nichols, J., O’Reilly, B., Oksanen, P., Peteet, D., Rchard, P., Robinson, S., Rundgren, M., Sannel, B., Tuittila, E.-S., Turetsky, M., Valiranta, M., van der Linden, M., van Geel, B., van Bellen, S., Vitt, D., Zhao, Y., Zhou, W., 2014. A database and synthesis of existing data for northern peatland soil properties and Holocene carbon accumulation. Holocene 24, 1028-1042.

Magny, M., Arnaud, F., Holzhauser, H., Chapron, E., Debret, M., Desmet, M., Leroux, A., Millet, L., Revel, M., Vannière, B., 2010. Solar and proxy-sensitivity imprints on paleohydrological records for the last millennium in west-central Europe. Quaternary Research 73, 173-179.

Magny, M., Gauthier, E., Vannière, B., Peyron, O., 2008. Palaeohydrological changes and humanimpact history over the last millennium recorded at Lake Joux in the Jura Mountains, Switzerland. The Holocene 18, 255-265.

Marcisz, K., Tinner, W., Colombaroli, D., Kołaczek, P., Słowiński, M., Fiałkiewicz-Kozieł, B., Łokas, E., Lamentowicz, M., 2015. Long-term hydrological dynamics and fire history during the last 
2000 years in CE Europe reconstructed from a high-resolution peat archive. Quaternary Science Reviews 112, 138-152.

Mazei, Y., Kabanov, A.N., 2008. Testate amoebae from the sedge-sphagnum forested mire in the north of Karelia (Russia). Izv. Penza. gos. pedagog. univ. im.i Vv. Gg. Bbelinskogo. 10, 101-104. Mazei, Y., Tsyganov, A.N., 2006. Freshwater testate amoebae. KMK, Moscow.

Mazei, Y.A., Embulaeva, E.A., 2009. Changes of soil-inhabited testate amoebae communities along forest-steppe gradient in the middle Volga region. Arid Ecosystems 15, 13-23.

Mazei, Y.A., Tsyganov, A.N., Bubnoba, O.A., 2009. The structure of amoeba communities in boggy biotopes of the southern Taiga (Russian European Part). Ucpiechi Sovriemennoi Biologii 129, 67-77.

Mazei, Y.A., Tsyganov, A.N., Bubnova, O.A., 2007. Structure of a community of testate amoebae in a Sphagnum dominated bog in upper sura flow (Middle Volga Territory). Biology Bulletin 34, 382-394.

Moore, P.D., Webb, J.A., Collinson, M.E., 1991. Pollen analysis. Blackwell Scientific Publication. Muller, S., Bobrov, A.A., Schirrmeister, L., Andreev, A.A., Tarasov, P.E., 2009. Testate amoebae record from the Laptev Sea coast and its implication for the reconstruction of Late Pleistocene and Holocene environments in the Arctic Siberia. Palaeogeography, Palaeoclimatology, Palaeoecology 271, 301-315.

Niklasson, M., Lindbladh, M., Björkman, L., 2002. A long-term record of Quercus decline, logging and fires in a southern Swedish Fagus-Picea forest. Journal of Vegetation Science 13, 765-774. Ogden, C.G., Hedley, R.H., 1980. An Atlas of Freshwater Testate Amoebae. Oxford University Press, London.

Oksanen, J., Blanchet, F.G., Kindt, R., Legendre, P., O’Hara, R.B., Simpson, G.L., Solymos, P., Stevens, M.H.H., Wagner., H., 2011. Vegan: Community Ecology Package. R package version 1.17-7.

Payne, R.J., Jassey, V.E.J., Leith, I.D., Sheppard, L.J., Dise, N.B., Gilbert, D., 2013. Ammonia exposure promotes algal biomass in an ombrotrophic peatland. Soil Biology and Biochemistry 57, 936938.

Payne, R.J., Lamentowicz, M., van der Knaap, W.O., van Leeuwen, J.F.N., Mitchell, E.A.D., Mazei, Y., 2012. Testate amoebae in pollen slides. Review of Palaeobotany and Palynology 173, 68-79. Payne, R.J., Mitchell, E.A.D., 2008. How many is enough? Determining optimal count totals for ecological and palaeoecological studies of testate amoebae. Journal of Paleolimnology 42, 483495.

Peregon, A., Uchida, M., Shibata, Y., 2007a. Sphagnum peatland development at their southern climatic range in West Siberia: Trends and peat accumulation patterns. Environmental Research Letters 2.

Peregon, A., Uchida, M., Shibata, Y., 2007b. Sphagnum peatland development at their southern climatic range in West Siberia: trends and peat accumulation patterns. Environmental Research Letters 2, 045014.

Pitkänen, A., Turunen, J., Tahvanainen, T., Tolonen, K., 2002. Holocene vegetation history from the Salym-Yugan Mire Area, West Siberia. Holocene 12, 353-362.

Qin, Y.M., Mitchell, E.A.D., Lamentowicz, M., Payne, R.J., Lara, E., Gu, Y.S., Huang, X.Y., Wang, H.M., 2013. Ecology of testate amoebae in peatlands of central China and development of a transfer function for paleohydrological reconstruction. Journal of Paleolimnology 50, 319-330.

Reimer, P.J., Bard, E., Bayliss, A., Beck, J.W., Blackwell, P.G., Ramsey, C.B., Buck, C.E., Cheng, H., Edwards, R.L., Friedrich, M., Grootes, P.M., Guilderson, T.P., Haflidason, H., Hajdas, I., Hatte, C., Heaton, T.J., Hoffmann, D.L., Hogg, A.G., Hughen, K.A., Kaiser, K.F., Kromer, B., Manning, S.W., Niu, M., Reimer, R.W., Richards, D.A., Scott, E.M., Southon, J.R., Staff, R.A., Turney, C.S.M., van der Plicht, J., 2013. Intcal13 and Marine13 Radiocarbon Age Calibration Curves 0-50,000 Years Cal BP. Radiocarbon 55, 1869-1887.

Seddon, A.W.R., Mackay, A.W., Baker, A.G., Birks, H.J.B., Breman, E., Buck, C.E., Ellis, E.C., Froyd, C.A., Gill, J.L., Gillson, L., Johnson, E.A., Jones, V.J., Juggins, S., Macias-Fauria, M., Mills, K., Morris, J.L., Nogues-Bravo, D., Punyasena, S.W., Roland, T.P., Tanentzap, A.J., Willis, K.J., Aberhan, M., van Asperen, E.N., Austin, W.E.N., Battarbee, R.W., Bhagwat, S., Belanger, C.L., Bennett, K.D., Birks, H.H., Ramsey, C.B., Brooks, S.J., de Bruyn, M., Butler, P.G., Chambers, F.M., Clarke, S.J., Davies, A.L., 
Dearing, J.A., Ezard, T.H.G., Feurdean, A., Flower, R.J., Gell, P., Hausmann, S., Hogan, E.J., Hopkins,

M.J., Jeffers, E.S., Korhola, A.A., Marchant, R., Kiefer, T., Lamentowicz, M., Larocque-Tobler, I., Lopez-Merino, L., Liow, L.H., McGowan, S., Miller, J.H., Montoya, E., Morton, O., Nogue, S., Onoufriou, C., Boush, L.P., Rodriguez-Sanchez, F., Rose, N.L., Sayer, C.D., Shaw, H.E., Payne, R., Simpson, G., Sohar, K., Whitehouse, N.J., Williams, J.W., Witkowski, A., 2014. Looking forward through the past: identification of 50 priority research questions in palaeoecology. Journal of Ecology 102, 256-267.

Sillasoo, U., Väliranta, M., Tuittila, E.S., 2011. Fire history and vegetation recovery in two raised bogs at the Baltic Sea. Journal of Vegetation Science 22, 1084-1093.

Solomeshch, A.I., 2005. The West Siberian Lowland in: Fraser, L.H., Keddy, P.A. (Eds.), The World's Largest Wetlands. Ecology and Conservation, pp. 11-62.

Stockmarr, J., 1971. Tablets with spores used in absolute pollen analysis. Pollen and Spores 16, 615-621.

Stocks, B.J., Mason, J.A., Todd, J.B., Bosch, E.M., Wotton, B.M., Amiro, B.D., Flannigan, M.D., Hirsch, K.G., Logan, K.A., Martell, D.L., Skinner, W.R., 2002. Large forest fires in Canada, 1959-1997. Journal of Geophysical Research 108.

Stocks, B.J., Wotton, B.M., Flannigan, M.D., Fosberg, M.A., Cahoon, D.R., Goldammer, J.G., 2001. Boreal Forest Fire Regimes And Climate Change, in: Beniston, M., Verstraete, M. (Eds.), Remote Sensing and Climate Modeling: Synergies and Limitations. Springer Netherlands, pp. 233-246. Swindles, G.T., Morris, P.J., Baird, A.J., Blaauw, M., Plunkett, G., 2012. Ecohydrological feedbacks confound peat-based climate reconstructions. Geophysical Research Letters 39.

Swindles, G.T., Plunkett, G., Roe, H.M., 2007. A multiproxy climate record from a raised bog in County Fermanagh, Northern Ireland: a critical examination of the link between bog surface wetness and solar variability. Journal of Quaternary Science 22, 667-679.

Swindles, G.T., Watson, E., Turner, T.E., Galloway, J.M., Hadlari, T., Wheeler, J., Bacon, K.L., 2015. Spheroidal carbonaceous particles are a defining stratigraphic marker for the Anthropocene. Scientific reports 5, 10264.

Team, R.D.C., 2013. R: A language and environment for statistical computing. R Foundation for Statistical Computing, Vienna, Austria. ISBN 3-900051-00-3, URL http://www.R-project.org. Tinner, W., Hu, F.S., 2003. Size parameters, size-class distribution and area-number relationship of microscopic charcoal: relevance for fire reconstruction. The Holocene 13, 499-505. Tobolski, K., 2000. Przewodnik do oznaczania torfów i osadów jeziornych, Vademecum Geobotanicum. Wydawnictwo Naukowe PWN, Warszawa p. 508 ss.

Tolonen, K., Warner, B.G., Vasander, H., 1994. Ecology of Testaceans (Protozoa: Rhizopoda) in mires in southern Finland: II. Multivariate analysis. Archiv für Protistenkunde 144, 97-112. Tsyganov, A.N., Komarov, A.A., Mitchell, E.A.D., Shimano, S., Smirnova, O.V., Aleynikov, A.A., Mazei, Y.A., 2015. Additive partitioning of testate amoeba species diversity across habitat hierarchy within the pristine southern taiga landscape (Pechora-Ilych Biosphere Reserve, Russia). European Journal of Protistology 51, 42-54.

Turetsky, M.R., Benscoter, B., Page, S., Rein, G., van der Werf, G.R., Watts, A., 2015. Global vulnerability of peatlands to fire and carbon loss. Nature Geosci 8, 11-14.

Turner, T.E., Swindles, G.T., Roucoux, K.H., 2014. Late Holocene ecohydrological and carbon dynamics of a UK raised bog: impact of human activity and climate change. Quaternary Science Reviews 84, 65-85.

Turunen, J., Tahvanainen, T., Tolonen, K., Pitkanen, A., 2001. Carbon accumulation in West Siberian mires, Russia. Global Biogeochemical Cycles 15, 285-296.

Tweiten, M.A., Hotchkiss, S.C., Booth, R.K., Calcote, R.R., Lynch, E.A., 2009. The response of a jack pine forest to late-Holocene climate variability in northwestern Wisconsin. Holocene 19, 10491061.

van Bellen, S., Garneau, M., Ali, A.A., Bergeron, Y., 2012. Did fires drive Holocene carbon sequestration in boreal ombrotrophic peatlands of eastern Canada? Quaternary Research 78, 5059.

Van Bellen, S., Mauquoy, D., Payne, R.J., Roland, T.P., Daley, T.J., Hughes, P.D.M., Loader, N.J., Street-Perrott, F.A., Rice, E.M., Pancotto, V.A., 2014. Testate amoebae as a proxy for 
reconstructing Holocene water table dynamics in southern Patagonian peat bogs. Journal of Quaternary Science 29, 463-474. van der Knaap, W.O., Lamentowicz, M., van Leeuwen, J.F.N., Hangartner, S., Leuenberger, M., Mauquoy, D., Goslar, T., Mitchell, E.A.D., Lamentowicz, Ł., Kamenik, C., 2011. A multi-proxy, highresolution record of peatland development and its drivers during the last millennium from the subalpine Swiss Alps. Quaternary Science Reviews 30, 3467-3480. Ward, S.E., Ostle, N.J., Oakley, S., Quirk, H., Henrys, P.A., Bardgett, R.D., 2013. Warming effects on greenhouse gas fluxes in peatlands are modulated by vegetation composition. Ecol Lett 16, 1285-1293. Wotton, B.M., Flannigan, M.D., 1993. Length of the Fire Season in a Changing Climate. Forest Chron 69, 187-192. 


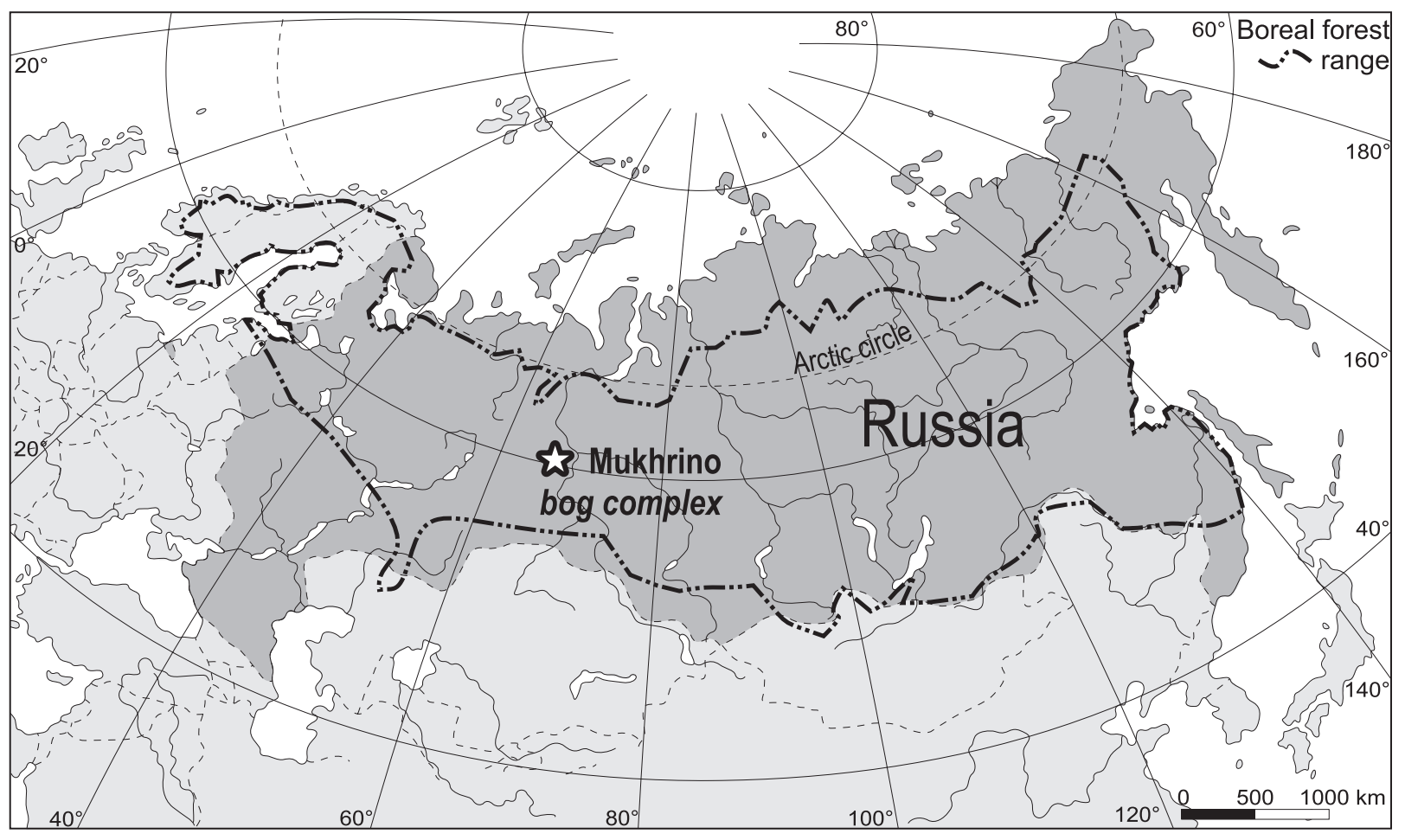

Fig. 1. 

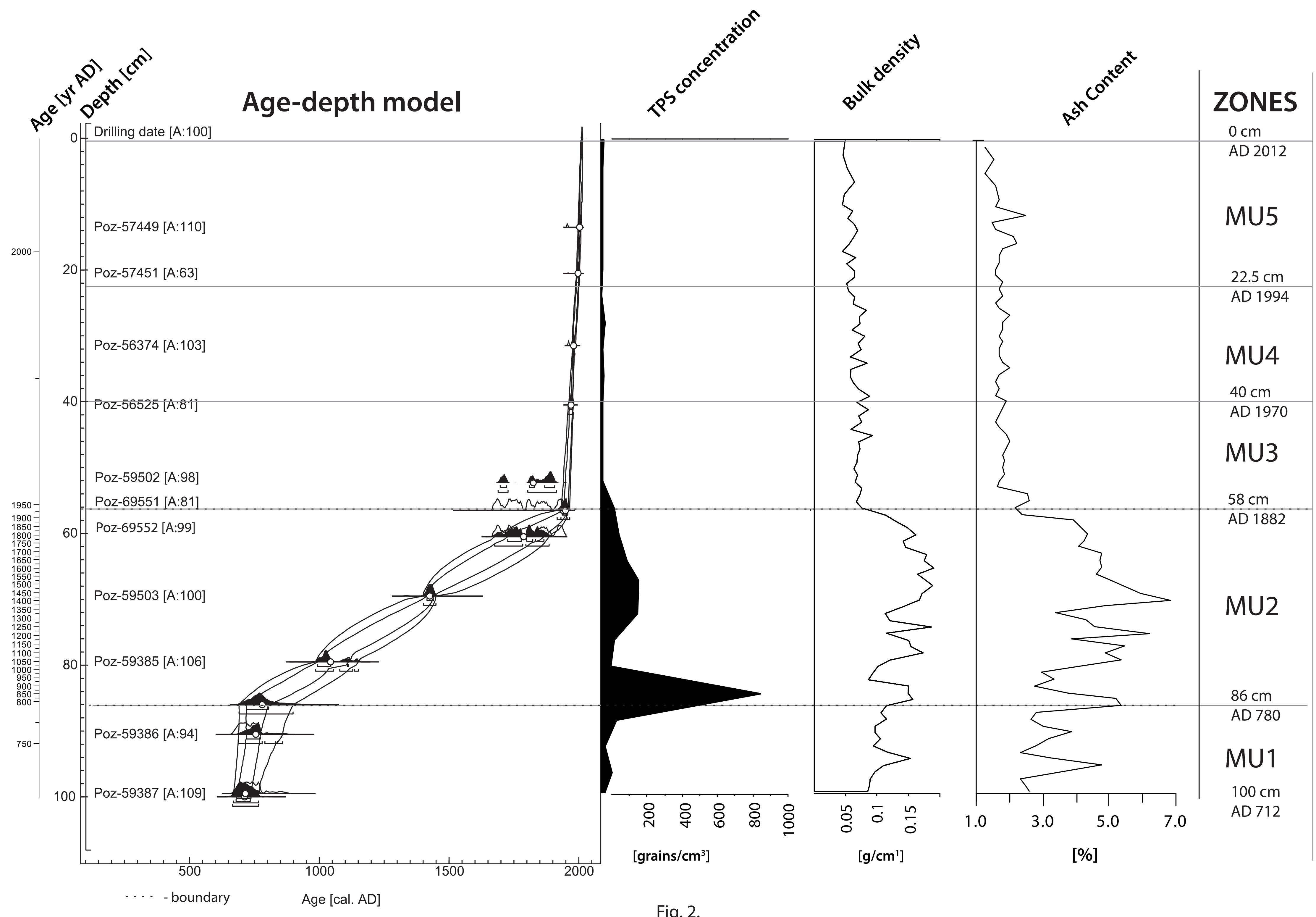

Fig. 2. 

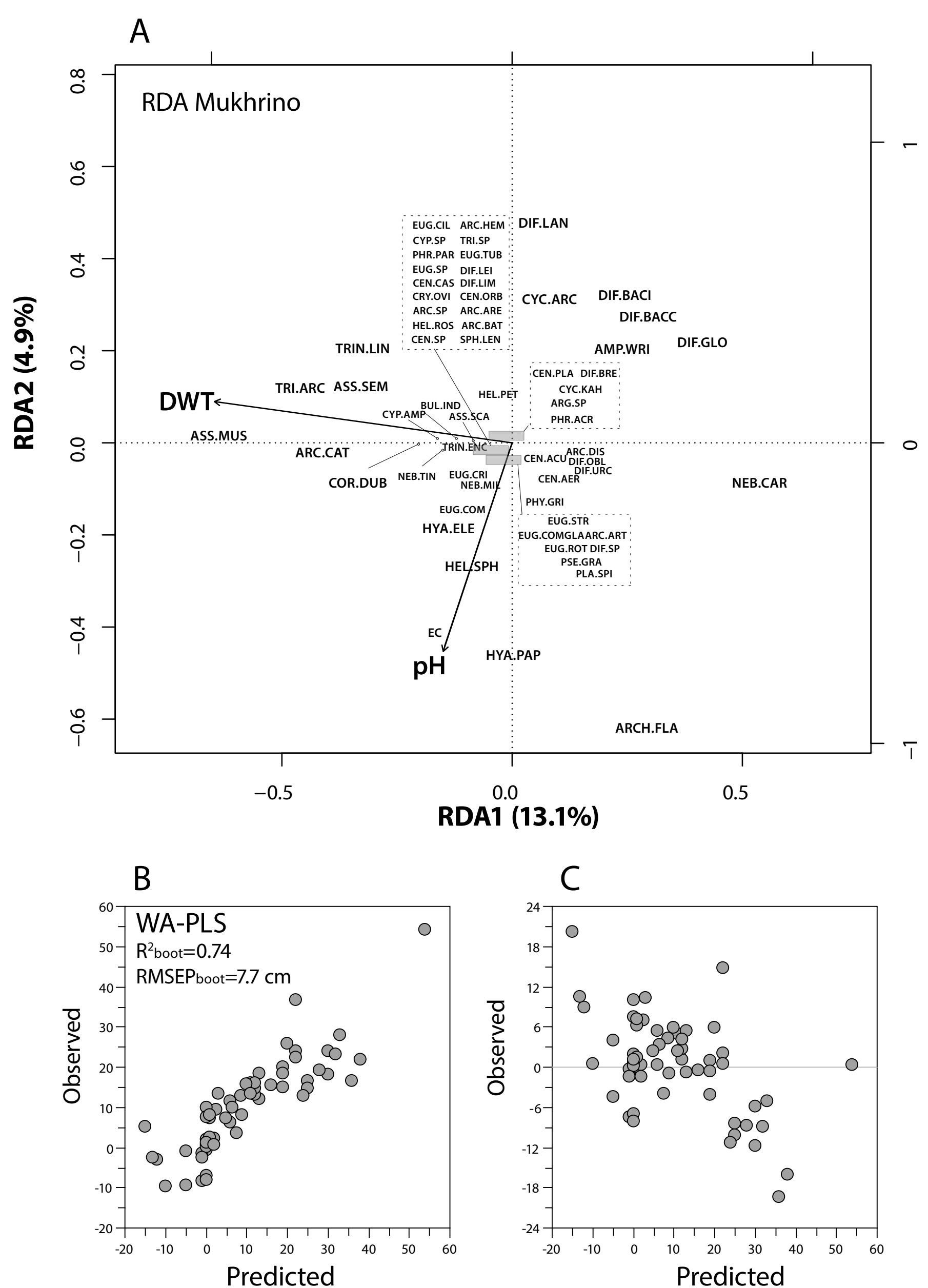

Fig. 3. 


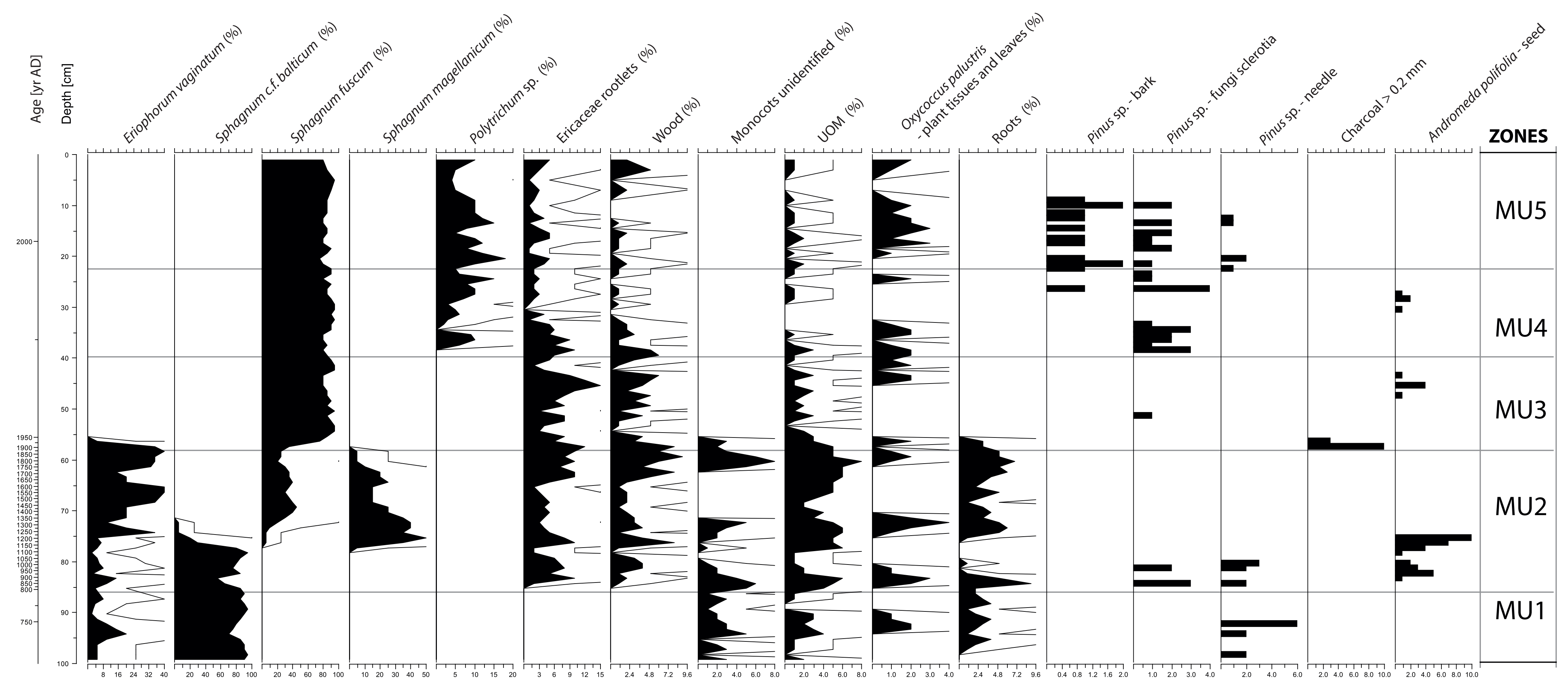

Fig. 4. 


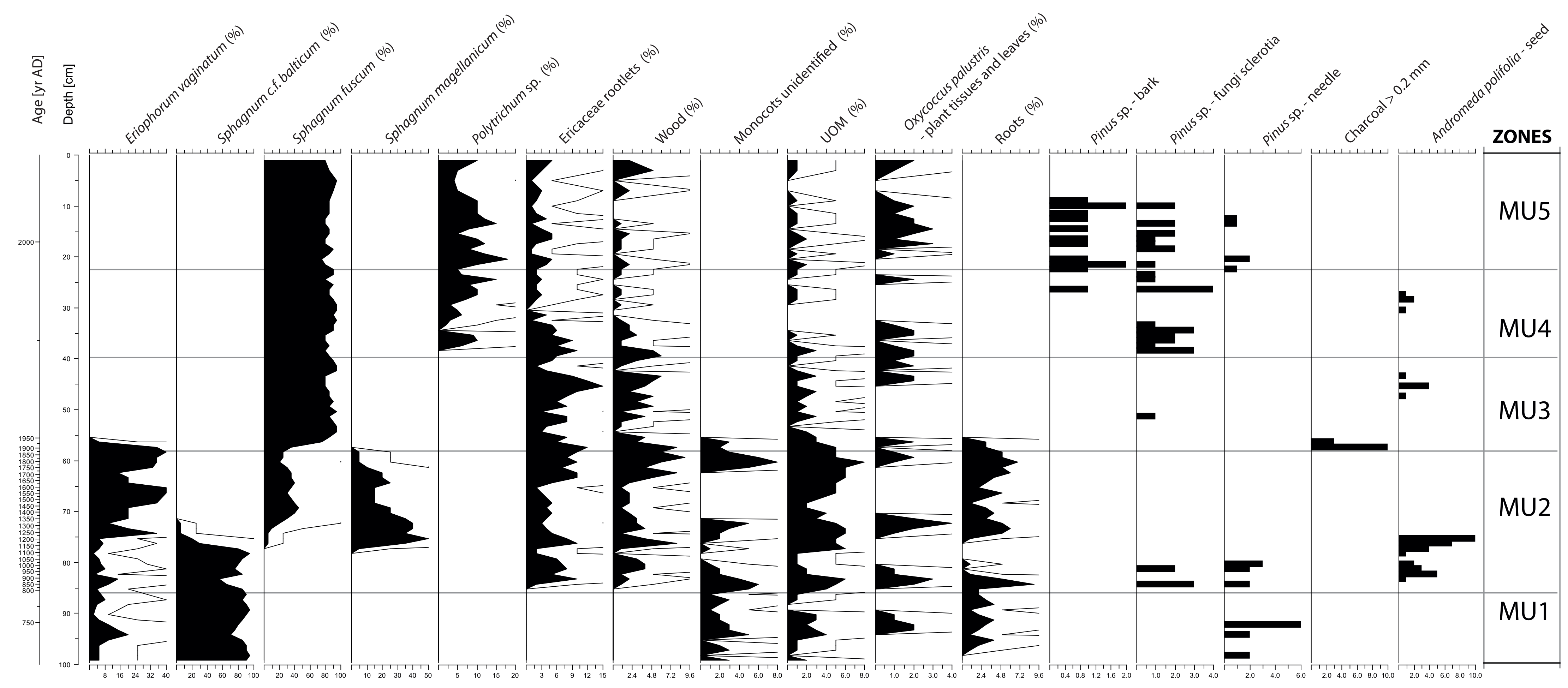

Fig. 4. 


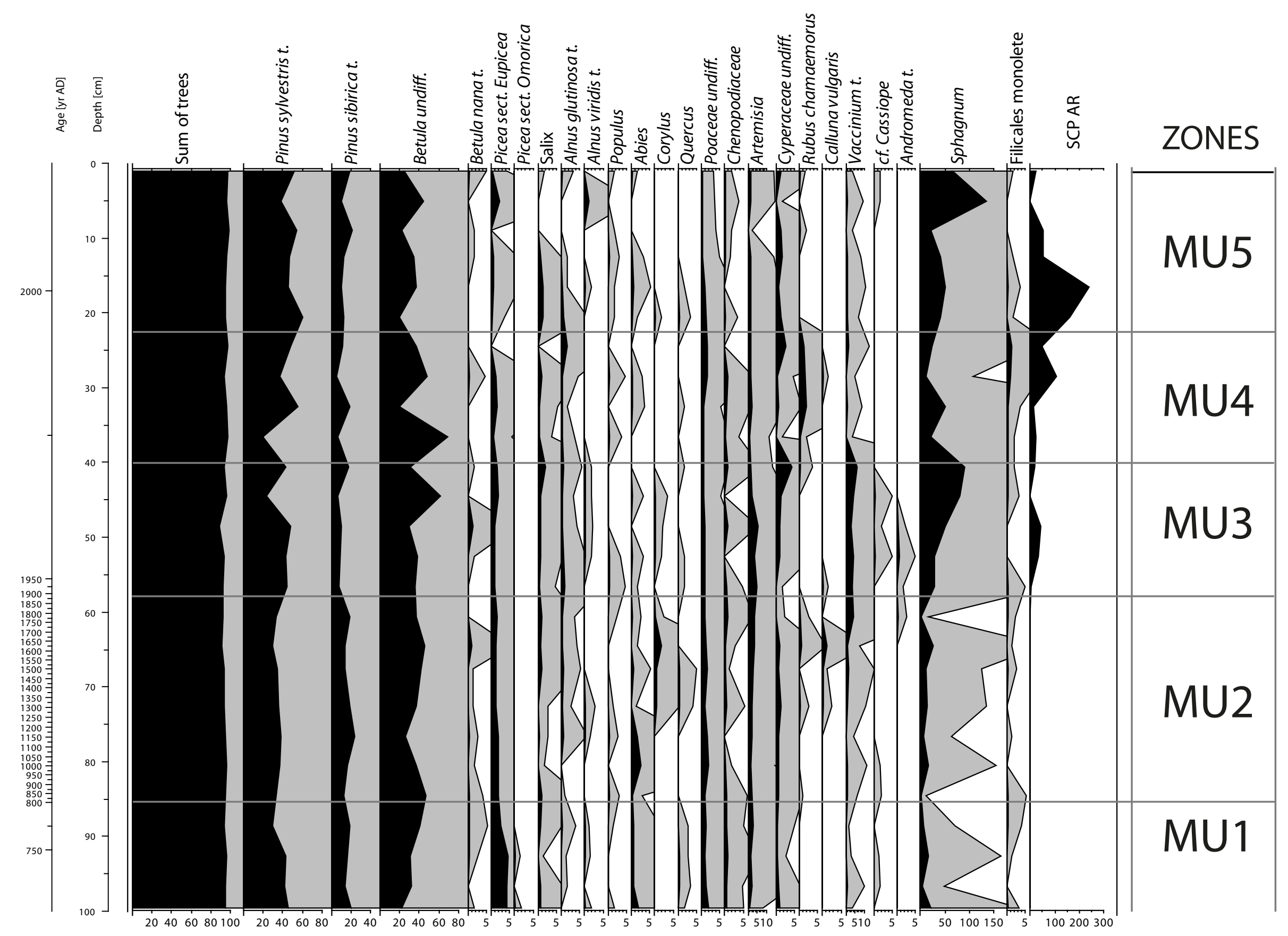

Fig. 5. 


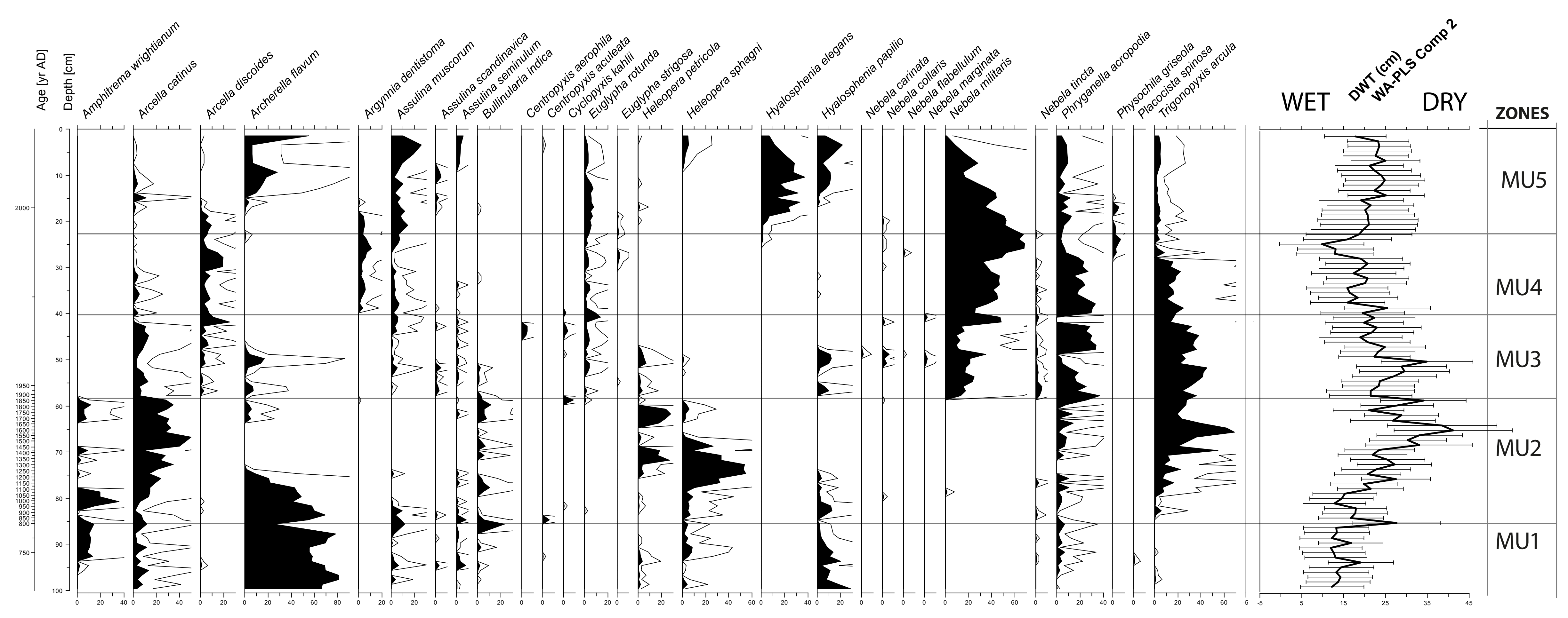




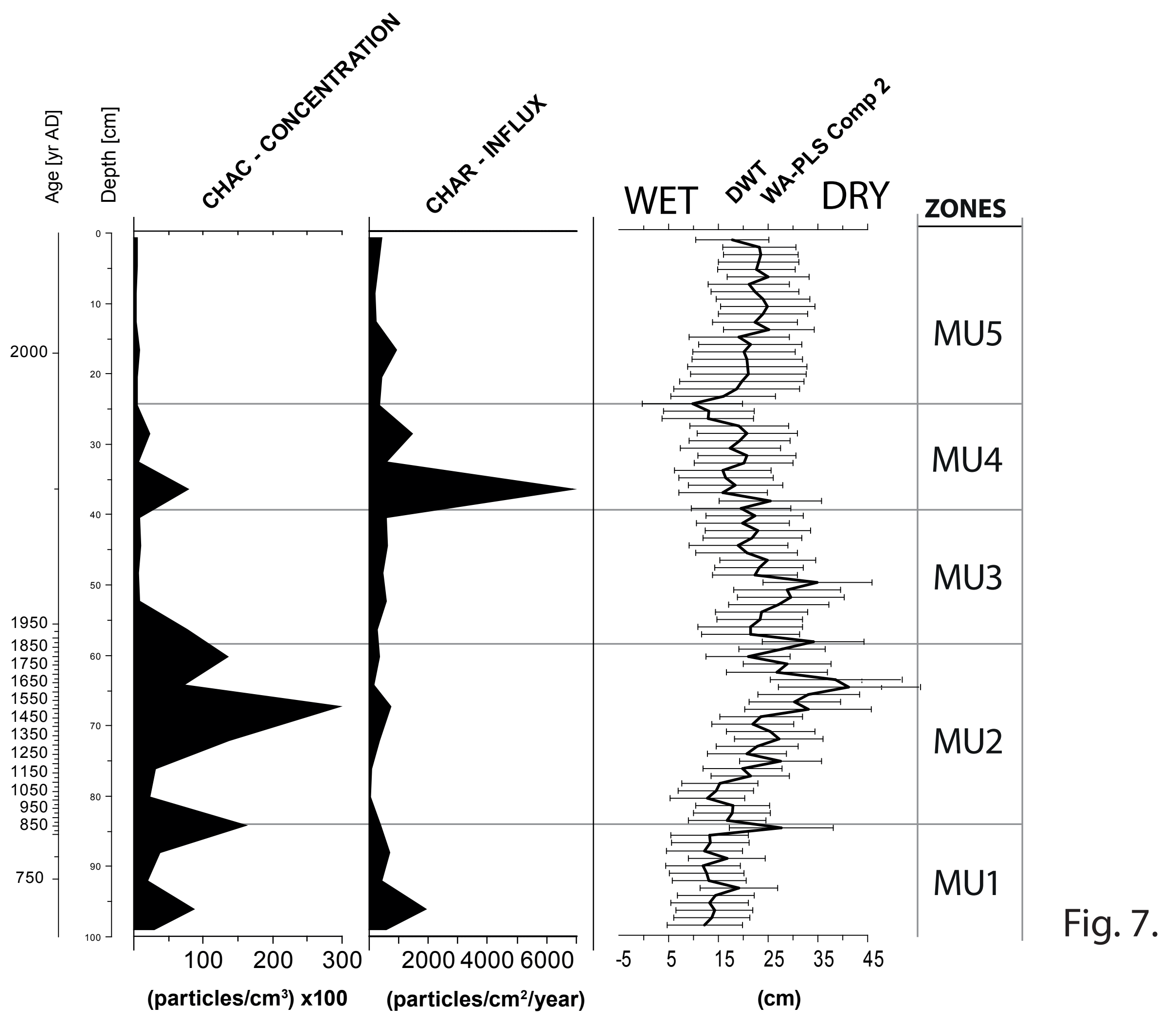


Table 1. Results of radiocarbon dating from the Mukhrino profile. Abbreviations: Poz - laboratory code of the Poznań Radiocarbon Laboratory (Poland)

\begin{tabular}{|c|c|c|c|c|}
\hline $\begin{array}{l}\text { Depth } \\
\text { [cm] }\end{array}$ & $\begin{array}{l}\text { Laboratory } \\
\text { code }\end{array}$ & Age $\left[{ }^{14} \mathrm{C}\right.$ yr BP $]$ & $\begin{array}{l}\text { Calibrated age, } 2 \sigma \text { range } \\
{[A D] ; \text { in brackets probability }} \\
\text { of the range of age }\end{array}$ & $\begin{array}{l}\text { Material selected to date; } \\
\text { remarks }\end{array}$ \\
\hline $13-14$ & Poz-57449 & $\begin{array}{l}107.81 \pm 0.34 \\
\text { pMC }\end{array}$ & $\begin{array}{c}1956-1957(3.7 \%) \\
2001-2005(91.7 \%)\end{array}$ & Sphagnum stems \\
\hline $20-21$ & Poz-57451 & $\begin{array}{l}110.13 \pm 0.33 \\
\text { pMC }\end{array}$ & $\begin{array}{l}1957(1.3 \%) \\
1996-2000(94.1 \%)\end{array}$ & Sphagnum stems \\
\hline $31-32$ & Poz-56374 & $\begin{array}{l}130.35 \pm 0.45 \\
\text { pMC }\end{array}$ & $\begin{array}{l}1961-1962(4.9 \%) \\
1978-1980(90.5 \%)\end{array}$ & Sphagnum stems \\
\hline $40-41$ & Poz-56525 & $\begin{array}{l}145.69 \pm 0.4 \\
\text { pMC }\end{array}$ & $\begin{array}{l}1962-1963(7.9 \%) \\
1972-1974(87.5 \%)\end{array}$ & Sphagnum stems \\
\hline $51-52$ & Poz-59502 & $70 \pm 30$ & $\begin{array}{l}1691-1730(24.3 \%) \\
1810-1924(71.1 \%)\end{array}$ & $\begin{array}{l}\text { Sphagnum stems; excluded } \\
\text { from age-depth modelling }\end{array}$ \\
\hline $56-57$ & Poz-69551 & $145 \pm 30$ & $\begin{array}{l}1668-1710(16.3 \%) \\
1717-1782(29.2 \%) \\
1797-1891(33.5 \%) \\
1909-1948(16.4 \%)\end{array}$ & Sphagnum stems \\
\hline $60-61$ & Poz-69552 & $140 \pm 30$ & $\begin{array}{l}1669-1780(43.1 \%) \\
1798-1891(36.8 \%) \\
1909-1945(15.5 \%)\end{array}$ & Sphagnum stems \\
\hline $69-70$ & Poz-59503 & $495 \pm 30$ & $1400-1450$ & Sphagnum stems \\
\hline $79-80$ & Poz-59385 & $995 \pm 30$ & $\begin{array}{l}986-1052(63.8 \%) \\
1081-1158(31.6 \%)\end{array}$ & Sphagnum stems \\
\hline $90-91$ & Poz-59386 & $1270 \pm 30$ & $\begin{array}{l}663-778(92.3 \%) \\
792-804(1.3 \%) \\
819-821(0.2 \%) \\
842-859(1.6 \%)\end{array}$ & Sphagnum stems \\
\hline $99-100$ & Poz-59387 & $1260 \pm 30$ & $\begin{array}{l}669-779(85.3 \%) \\
791-829(5.9 \%) \\
838-865(4.2 \%)\end{array}$ & Sphagnum stems \\
\hline
\end{tabular}


Table 2.Transfer function performance statistics. The best model is Weighted Averaging Partial Least Squares Component 2

\begin{tabular}{|c|c|c|c|c|}
\hline Model & R2 & Ave_Bias & Max_Bias & RMSEP \\
\hline \multicolumn{5}{|l|}{ PLS } \\
\hline PLS Component 1 for WT & 0,51 & 0,33 & 40,51 & 10,34 \\
\hline PLS Component 2 for WT & 0,64 & 0,23 & 28,31 & 8,90 \\
\hline PLS Component 3 for WT & 0,68 & 0,07 & 23,67 & 8,49 \\
\hline PLS Component 4 for WT & 0,67 & $-0,09$ & 19,52 & 8,73 \\
\hline PLS Component 5 for WT & 0,65 & $-0,26$ & 16,03 & 9,47 \\
\hline \multicolumn{5}{|l|}{ WAPLS } \\
\hline WAPLS Component 1 for WT & 0,63 & 0,34 & 23,21 & 8,60 \\
\hline WAPLS Component 2 for WT & 0,74 & $-0,28$ & 17,74 & 7,70 \\
\hline WAPLS Component 3 for WT & 0,73 & $-0,91$ & 15,56 & 8,43 \\
\hline WAPLS Component 4 for WT & 0,72 & $-1,08$ & 17,39 & 9,06 \\
\hline WAPLS Component 5 for WT & 0,71 & $-1,15$ & 16,61 & 9,59 \\
\hline \multicolumn{5}{|l|}{ WA } \\
\hline Weighted averaging model (inverse deshrinking) for WT & 0,64 & 0,28 & 22,12 & 8,54 \\
\hline Weighted averaging model (classical deshrinking) for WT & 0,65 & 0,36 & 16,79 & 9,18 \\
\hline Weighted averaging model (tolerance downweighted, inverse deshrinking) for WT & 0,75 & 0,62 & 18,12 & 7,88 \\
\hline Weighted averaging model (tolerance downweighted, classical deshrinking) for WT & 0,75 & 0,77 & 16,35 & 8,11 \\
\hline
\end{tabular}

